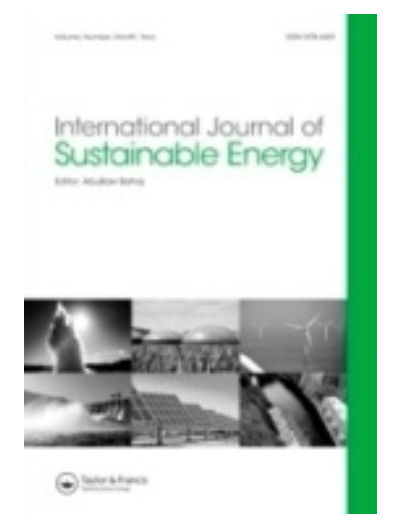

\title{
Exploring the effect of the renewable energy transition on CO2 emissions of Latin American \& Caribbean countries
}

\begin{tabular}{|r|l|}
\hline Journal: & International Journal of Sustainable Energy \\
\hline Manuscript ID & gSOL-2019-0408.R1 \\
\hline Manuscript Type: & Original paper \\
\hline Date Submitted by the & $\mathrm{n} / \mathrm{a}$ \\
\hline Complete List of Authors: & $\begin{array}{l}\text { Koengkan, Matheus; Federal Fluminense University, Department of } \\
\text { Economics; CEFAGE; University of Évora, Department of Economics } \\
\text { Fuinhas, José; NECE-UBI; CEBER; Universidade de Coimbra Faculdade } \\
\text { de Economia }\end{array}$ \\
\hline Keywords: & $\begin{array}{l}\text { Energy economics, Energy, Econometrics, Energy transition, Trade } \\
\text { openness, Latin America \& Caribbean }\end{array}$ \\
\hline &
\end{tabular}

\section{SCHOLARONE $^{\text {TM }}$ Manuscripts}




\title{
Exploring the effect of the renewable energy transition on $\mathrm{CO} 2$ emissions of Latin American \& Caribbean countries
}

\author{
Matheus Koengkan ${ }^{*}, 1,2$, and José Alberto Fuinhas ${ }^{3}$ \\ ${ }^{1}$ Department of Economics, Federal Fluminense University, Niterói, Brazil \\ ${ }^{2}$ CEFAGE-UE and Department of Economics, University of Évora, Évora, Portugal \\ ${ }^{3}$ NECE-UBI, CeBER, and Faculty of Economics, University of Coimbra, Coimbra, Portugal
}

\begin{abstract}
This article investigates the effect of the renewable energy transition on $\mathrm{CO} 2$ emissions of Latin American \& Caribbean (LAC) countries in the period from 1990 to 2014. To this end, a panel autoregressive distributed lags (PARDL) model in the form of an unrestricted errorcorrection model (UECM) is estimated. The PARDL indicates that the ratio of renewable energy that is a proxy of the renewable energy transition in the short and long run has a negative impact on emissions of $\mathrm{CO} 2$ of -0.0675 and -0.0313 respectively. That is, the process of the energy transition can mitigate environmental degradation in LAC countries. Moreover, the empirical results also indicate that economic growth, trade openness and urbanisation contribute to the increase in $\mathrm{CO} 2$ emissions.
\end{abstract}

Keywords: Energy economics; Energy; Econometrics; Energy transition; Latin America \& Caribbean.

\section{Introduction}

This investigation arises in a moment in which the renewable energy transition has accelerated and become an area of policy concern for many governments. Energy transition does not occur in a vacuum. It was shaped and influenced over time by a broad and deep shift in the planet, politics, progress and prosperity. The energy transition is not just about energy or change in energy sources or a simple replacement of technology for one more efficiently. It is a deep paradigm shift that has changed in the energy world, where a change exists in the values of security, robustness and reliability. Therefore, the existing energy systems that were built with these values have been replaced by new systems with values of sustainability, affordability and flexibility that allowed a new way of producing and consuming energy.

In the literature there is no precise term for "energy transition". Smil (2010) points out that it does not have a precise or widely accepted meaning. However, this term is often used to describe changes in the energy matrix from fossil to renewable. This change takes place progressively from an established energy system (fossil) to a new one (renewable). Therefore, this change process can be analysed from a global perspective to local one. Hauff et al. (2014) used the term "energy transition" for a structural transformation in the energy sector, indicating a growing trend of the share of renewable energy sources combined with the promotion of energy

\footnotetext{
* Corresponding Author: matheuskoen@hotmail.com.br; Federal Fluminense University, Department of Economics, Campus do Gragoatá - Bloco F - São Domingos - Niterói-Rio de Janeiro, 24210-350, Brazil.

${ }^{1}$ Federal Fluminense University, Department of Economics, Campus do Gragoatá - Bloco F - São Domingos - Niterói-Rio de Janeiro, 24210-350, Brazil.

${ }^{2}$ Department of Economics, University of Évora, Colégio do Espírito Santo, Largo dos Colegiais, 2 ,7000803 Évora, Portugal.

${ }^{2}$ Research supported by: National Funds of the FCT - Portuguese Foundation for Science and Technology within the project UID/ECO/04007/2019.

${ }^{3}$ Faculty of Economics, University of Coimbra, Av. Dr. Dias da Silva 165, 3004-512 Coimbra, Portugal.

${ }^{3}$ Centre for Business and Economics Research - CeBER.

${ }^{3}$ Research supported by: NECE, R\&D unit funded by the FCT - Portuguese Foundation for the Development of Science and Technology, Ministry of Science, Technology and Higher Education, project UID/GES/04630/2019.
} 
efficiency to reduce the consumption of non-renewable energy. Indeed, this term gives a clear objective of reducing environmental degradation. This definition is misinterpreted, consequently reducing the conceptual scope of the term by emphasising one type of change, namely from nonrenewable energy sources to renewable. Moreover, there is not one single energy transition but rather various local experiences.

Indeed, the renewable energy transition and energy efficiency have been the two main international action priorities to mitigate the effects of global warming and climate changes (World Energy Council Report, 2019, pp. 6-10). This is a result of the uncontrolled increase in the level of carbon dioxide emissions ( $\mathrm{CO} 2)$ that consequently has set off a worldwide alarm signal (Fuinhas et al., 2017). This increase is a significant contributor to greenhouse gas emissions (GHGs) and consequently to global warming and climate change (Koengkan et al., 2019c). The three leading greenhouse gases that contribute to climate change are carbon dioxide $(77 \%)$, nitrous oxide (8\%), and methane (14\%) (Khan et at., 2014).

Global GHGs, mainly CO2 emissions, have been increasing since the 1970s (IPCC, 2014, p. 5) (see Figure 1 in Appendix). However, during the period between 1990 to 2014, these emissions grew most rapidly, where in 1990 the GHGs were 33 megatons of $\mathrm{CO} 2$ equivalent (MtCO2eq) and in 2014 reached $48 \mathrm{MtCO} 2 \mathrm{eq}$, that is an increase of 1.5\% during this period (Bárcena et al., 2019, p. 19). Bárcena et al. (2019, p. 23), points out that $78 \%$ of this increase is related to the consumption of energy (69\%) and industrial processes (9\%). Khan et al. (2014) confirm this affirmation, with most of these emissions emanating from the residential and industrial sector that are a direct result of the consumption of energy. GHGs take place through direct emissions from the combustion of fossil fuels for cooking, heating, cooling and providing power.

In the Latin America and the Caribbean (LAC) region it is no different from the rest of World, with GHGs undergoing an increase of $0.7 \%$ between 1990 and 2014; in 1990 the emissions were 3,414 MtCO2eq and in 2014 the emissions reached 4,020 MtCO2eq. Indeed, 70\% of this increase is related to the consumption of energy (35\%) and change in land use and forestry (35\%) (Bárcena et al., 2019, p. 23). This has also been found by Koengkan et al. (2019c), where liquid fuels account for $60.8 \%$ of total $\mathrm{CO} 2$ emissions in the LAC region, with coal being only a modest contributor, with $7.6 \%$ in 2013.

Regarding the structure of GHGs in LAC region, in 1990 the energy sector had a participation of $28 \%$, change in land use and forestry $45 \%$, agriculture $21 \%$, industrial processes $2 \%$, waste $4 \%$ and boiler fuels $1 \%$, while in 2014 the consumption of energy had a participation of $46 \%$, agriculture $23 \%$, changes in land use and forestry $19 \%$, in industrial processes $4 \%$, waste $6 \%$, and boiler fuels $\%$ (Bárcena et al., 2019, p. 23). Despite the growth in emissions between 1990 and 2014, the region is a small contributor per capita to the world's GHGs, accounting for about $11 \%$ of total global emissions (Fuinhas et al., 2017).

This increase in GHGs in the LAC region is directly related to economic growth in the region, which increases the consumption of energy and consequently, emissions. According to World Bank Open Data (2019), the LAC's GDP per capita growth (annual \%) had an average annual growth rate of approximately 1.44\% between 1989 and 2014. In 1989 the GDP per capita (current US\$) was US\$2,319.10, and in 2014 it was US\$10,405.50 (see Figure 2 in Appendix). This increase in GDP per capita is related to the structural and stabilisation programmes indicated by the International Monetary Fund (IMF) that the Latin American countries adopted. These programmes of adjustment are basically neoliberal policies that consist mainly of the complete opening of their economies to international capital and trade, reduction of public expenditure, deregulation of the economy, privatisation, the retreat of the role of the state and the creation of appropriate conditions for foreign investment (Ahumada and Andrews, 1998). Also, the "commodity boom" that occurred between 2004 to 2014 accelerated the process of insertion and economic growth of LAC economies (Carneiro, 2012).

The consumption of energy followed the same trend of GDP per capita growth, where according to World Bank Open Data (2019), in 1989 electric power consumption (kWh per capita) was 1175.35 ( $\mathrm{kWh}$ per capita), and in 2014 the consumption had reached 2155.70 (kWh per capita) (see Figure 3 in Appendix). Balza et al. (2016) point out that total energy consumption increased from 190 million tonnes of oil equivalent (MTOE) in 1971 to 610 MTOE in 2013, 
which is $220 \%$ higher than in the early 1970 s and represented an average annual growth rate of $2.8 \%$. Indeed, the transport and industrial sector accounted for more than 302 MTOE of this increase. According to World Bank Open Data (2019), in $198970.84 \%$ of this electric power consumption came from fossil fuels energy sources, and in 2014 this value reached $73.3 \%$ of the total of energy consumption (see Figure 4 in Appendix).

All this made clear the importance of the energy sector for initiatives to mitigate these emissions. Therefore, energy planning must consider a scenario of climate change, where additional efforts are necessary directed at limiting emissions from the energy sector, especially in developing countries such as the LAC countries, where there are expectations of an increase in the energy demand. Indeed, the renewable energy transition is a part of the solution and will play an essential role in mitigating the energy consumption from fossil fuels that are responsible for GHGs emissions, environmental degradation and the increase in global climate changes.

In the LAC region, the renewable energy transition began in the 1970s in Brazil with the Proalcool programme which started in 1975 after the first oil shock in 1973 (Gielen et al., 2019). This programme is a mix of policy instruments that evolve and are mainly used to substitute for imported petroleum and to address the needs of both supply and demand sides (Gielen et al., 2019; Solomon and Krishna, 2011). Moreover, this programme drives biomass-based ethanol demand, but the sector's long-term success continues to be impacted by economic cycles and changing government priorities (Gielen et al., 2019). Other initiatives of energy transition arose in the region in the same decade, such as the geothermal programme in Costa Rica in 1976 and Nicaragua in 1977 (Fuinhas et al., 2017), the development of large hydropower in Brazil and Paraguay in 1971-1984 with the binational Itaípu dam and other small hydro projects (Flavin et al., 2014), in Argentina with biomass, biogas, hydropower plants, geothermal, wind, wave and photovoltaic plants in 1998 and in Venezuela (RB) with hydropower plants in 2001 (Koengkan et al., 2019a).

The Latin American region has the largest share of hydroelectricity over total electricity generation in the world, with hydroelectricity representing 55\% of the energy mix; a sizable proportion when compared with the world average of 17\% (Koengkan et al., 2018a). Flavin et al. (2014) point out that in the 1970s the participation of hydroelectricity (e.g., small and large hydro) in the total electricity generation in the LAC region was $55 \%$, in the 1990 s the participation increased to $67 \%$, and in 2013 the participation decreased to 51\%. However, the share of electricity from hydro declined since the end of the 1990s due to the development of other energy sources from natural gas and new renewable energy sources (e.g., geothermal, solar, small hydro, wind, waste and marine) (Flavin et al., 2014).

The new renewable energy sources have had rapid growth since the end of the 1990s and in 2012 comprised only $9 \%$ of total installed power capacity in LAC region, where $4 \%$ is from biomass and waste, $3 \%$ geothermal, and $2 \%$ wind. Moreover, the installed capacity of these energy sources more than doubled between 2006 and 2012, where the installed capacity in 2006 was 11.3 gigawatt $(\mathrm{GW})$ and in 2012 reached $26.6 \mathrm{GW}$. This increase was driven by biomass and waste which make up most of this growth and by the significant development of small hydro and wind (Flavin et al., 2014). Indeed, this increase is a result of high investments that were made in renewable energy (e.g., marine, wind, solar, small hydropower, geothermal, solid biofuels and waste and liquid biofuels), which was 4.6 US\$ billion in 2005 and in 2015 reached 16.4 US\$ billion (IRENA, 2016). In this period, investments in renewable energy sources grew 13\% between the 2000s and 2013 (Koengkan et al., 2019d). Moreover, according to World Bank Open Data (2019), the consumption of renewable energy in the LAC region was $32.43 \%$ of total energy consumption in 1990 and in 2014 reached a value of $27.08 \%$.

This rapid expansion of renewable energy in the LAC region is associated with the fast process of globalisation in the region that exerts a positive impact on economic growth and consequently increases energy demand; in order to meet the energy demand, new investments in renewable energy technologies are necessary (Koengkan et al., 2019d). Moreover, the globalisation has also facilitated access to technological advances via trade liberalisation that consequently contribute to the increase in renewable energy capacity in the region (Koengkan et al., 2019c). Additionally, trade openness allows developing countries to import energy-saving technologies, products and/or processes from developed countries that consume less energy. That 
is, in developing countries, the reduction of energy consumption is more visible than in developed countries because the developing countries have more capacity to absorb the transferred technologies than developed ones (Ghani, 2012). The economic integration in Latin American countries allows access to new energy technologies which have consequently been adopted in their industries. However, this technology transfer to renewable energy in the Latin America region depends on the production and absorption capacity and the path dependency of significant investment in new technologies (Koengkan et al., 2019c).

In the LAC region, this process of trade liberalisation began in the 1970s in Chile with the profound shift toward free-market economies during the dictatorship of Pinochet (Ahumada and Andrews, 1998, p. 452). On the other hand, in many other countries from the region, the implementation of the neoliberal economic model has taken place during the process of the "Washington consensus", which is a combination of measures to promote the "macroeconomic adjustment" and by the "Brady plan", which is an external debt restructuring plan (Koengkan et al., 2019e). This adjustment occurred between 1989 and 1992, where Costa Rica and Mexico (1989), Venezuela (RB) (1990), Uruguay (1991), Argentina (1992), and Brazil (1992) passed schemes for deep trade and financial liberalisation, with privatisation of significant portions of the public sector, liberalisation of foreign investment, reduction of import barriers and the development of economic stabilisation programmes (Vásquez, 1996; Aizenman, 2005). These schemes were developed in order to put the LAC economies "back on track" (Koengkan et al., 2019e). Indeed, before this adjustment, the average annual compound growth rate was approximately $-0.5 \%$ between 1980 to 1989 and later, with "macroeconomic adjustment", the LAC's GDP per capita had an average annual compound growth rate of approximately $2.2 \%$ between 1989 and 1994 (Hofman, 2000, p. 32). In the 1990s, as mentioned before, the LAC region grew and integrated into the world. Indeed, in the first half of the 1990s, most LAC countries adopted unilateral opening policies, reducing their tariffs and eliminating other trade restrictions. Moreover, in this period several regional agreements within the framework of Asociación Latinoamericana de Integración (ALADI) were strengthened, for example, Mexico joined the North American Free Trade Agreement (NAFTA) and the Common Market of the South (Mercosur) was created. Between 1990 and 1999, LAC imports grew at an average rate of $11 \%$ while exports increased at an average rate of $8.1 \%$, improving its share in world trade (Terra, 2003 , p. 138). Hence, trade in the LAC region in the 1990s was characterised by imports growing at rates far higher than those of exports. It should be recalled that imports had been drastically reduced in the wake of the debt crisis that followed the Mexican financial crisis of 1982 (VenturaDias et al., 1999, p. 20). Then, in this period, imports had a vital role to play in the modernisation of the production process, where modern machines and better industrial inputs contributed to the technological upgrading of the industrial base in the region (Ventura-Dias et al., 1999, p. 20). According to World Bank Open Data (2019), in 1989 trade (\% of GDP) in the region was 31.7\% and at the end of 2003 the value rose to $42.8 \%$ (see Figure 5 in Appendix), an increase of 35.01\% between 1989 and 2003.

However, this process of trade liberalisation that began in the 1970s intensified with "commodities boom" that occurred between 2004 and 2014, where the region had an average growth rate of $7.40 \%$ (Santos, 2015). According to Carneiro (2012), the cycle of commodity prices in Latin American economies impacted the degree of economic openness or more precisely, the degree of dependence of external demand vis-à-vis domestic demand or markets. The same author adds that between 1990 and 1993, the degree of economic openness was 28.6, between 1998 and 2001 it was 38.5, and between 2006 to 2009 it was 44.7 on a scale of $0-100$, where 100 represents an open economy. That is, in this period between 1990 and 2009, the degree of economic openness had a growth of $50.71 \%$.

Furthermore, this fact seems to have allowed the region to surpass the problems generated by the 2008-2009 financial crisis (Koengkan et al., 2019c). Indeed, the growth in the degree of economic openness was caused by an increase in exports and imports in the region, where according to World Bank Open Data (2019), in 2004 export of goods and services (BoP current US\$) was US\$1,091.28 and reached a value of US\$2,218.43 in 2014, while import in 2004 was US\$983,47 and reached a value of US\$2,348.50 in 2014 (see Figure 6 in Appendix). Indeed, according to ECLAC (2018), the growth in the manufacturing sector caused by the commodities 
boom led to foreign direct investment (FDI) inflows in the largest economies in the region, with $61 \%$ of total FDI inflows in Mexico and 38\% in Brazil. The renewable energy sector received 5\% of these FDI inflows from 2005 to 2007. However, it was from 2015 to 2017 that this sector was the main recipient of new FDI inflows and received $26 \%$ of them. Investments in new renewable energy, domestic and foreign, in 2017 reached US\$6.2 billion each in Brazil and Mexico, US\$1.8 billion in Argentina, and US $\$ 1.5$ billion in Chile. Most projects in these countries involved foreign companies. Moreover, most of these investments were made in solar (35\%) and wind $(32 \%)$ technology between 2005 to 2017.

Indeed, this rapid economic growth caused by trade liberalisation as mentioned before influenced the process of urbanisation in LAC countries. The region is highly urbanised and the LAC region has four global cities, São Paulo (Brazil), Mexico City (Mexico), Buenos Aires (Argentina), and Rio de Janeiro (Brazil). This process of urbanisation in these countries made the urban population grow to $30 \%$ in the 1940 s, $60 \%$ in 1970 s, and in 2000 s $80 \%$ of the people were living in cities. It means that the most important urban centres such as Buenos Aires, São Paulo, Rio de Janeiro and Mexico City had an increase of $10 \%$ of the urban population in specific periods (Martins, 2002).

The relevance of the events described inspired the main research question of this investigation, namely: What is the effect of the renewable energy transition on $\mathrm{CO} 2$ emissions in LAC countries? The specific question resulting from the deepening of the central question is an objective one: Do trade openness and urbanisation increase the emissions of $\mathrm{CO} 2$ in the LAC region? To answer this question, analysis of the effect of the renewable energy transition on $\mathrm{CO} 2$ emissions of Latin American \& Caribbean countries is carried out, using data for eighteen countries from the LAC region, estimating the panel autoregressive distributed lags (PARDL) model in the form of unrestricted error-correction model (UECM).

This investigation is innovative in the literature for the following reasons: (i) the use of the ratio of renewable energy as a proxy of energy transition, as well as the use of trade openness instead of exports and imports, bearing in mind the fact that both are not duly used and dealt with in the literature; (ii) the use of PARDL in the form of UECM to investigate this relationship; (iii) the new approach using LAC countries, bearing in mind that this region is not outlined in the literature; and (iv) this investigation thoroughly explains how the variables are related if compared with other studies.

The motivation that drives the realisation of this investigation is related to the rapid increase in $\mathrm{CO} 2$ emissions in the LAC region. These emissions have more than doubled and have set off an alarm signal, causing major concern in the political context and in society in general. Indeed, there is a global consensus that fossil fuel consumption is one of the main factors responsible for both the increase in emissions and the anthropogenic climate change. However, the renewable energy transition is a part of the solution and will play an essential role in mitigating energy consumption from fossil fuels, which are responsible for GHGs emissions, environmental degradation and the increase in global climate changes. Thus, in order to identify if the renewable energy transition mitigates these emissions, this investigation is being carried out.

Moreover, this investigation is essential and will contribute to the literature for the following reasons: (i) it is necessary to understand how the process of renewable energy transition decreases the environmental degradation in the countries of the LAC region; (ii) the results of this research have critical consequences for the local governments appraise of the relationship between renewable energy transition and $\mathrm{CO} 2$ emissions; (iii) this article will help policymakers develop appropriate energy policies aimed at reducing the consumption of fossil fuels, as well as encouraging the development and consumption of renewable energy technologies in order to mitigate the $\mathrm{CO} 2$ emissions in the LAC region; and (iv) the empirical findings will complement the gap in the literature on this field.

The article is organised as follows: Section 2 reviews the relevant literature; Section 3 presents the data and the methodology; Section 4 describes the empirical analysis; Section 5 discusses the obtained results, and Section 6 presents the conclusions and policy implications.

\section{Literature review}


In the literature, the effect of the energy transition on $\mathrm{CO} 2$ emissions in the $\mathrm{LAC}$ region has not been explored, and there is a scarcity of investigations approaching this topic. Therefore, this investigation will opt to use literature-based studies that investigated similar topics as will the structure of the investigation, in this case, studies that explored the impact of renewable energy consumption on emissions of CO2 (e.g., Aydoğan and Vardar, 2019; Mbarek et al., 2018; Koengkan et al., 2018a; Fuinhas et al., 2017; Koengkan and Fuinhas, 2017; Bilgili et al., 2016; Shafiei and Salim, 2014; Apergis and Payne, 2014; Sadorsky, 2009; Akella et al., 2009). Indeed, this literature was reviewed bearing in mind that it is the closest to the topic under discussion.

Even though several investigations have used different countries, variables, methodologies and time span to explain the impact of the energy transition on emissions of $\mathrm{CO} 2$, the best approach to achieve it remains unresolved. What conclusions, then, have been reached by the literature about the impact of renewable energy consumption on $\mathrm{CO} 2$ emissions? The literature that approaches this relationship has evolved in two divergent ways. The first argues that renewable energy consumption mitigates ecological degradation (e.g., Aydoğan and Vardar, 2019; Mbarek et al., 2018; Fuinhas et al., 2017; Koengkan and Fuinhas, 2017; Bilgili et al., 2016; Shafiei and Salim, 2014; Akella et al., 2009). Concerning the negative impact of renewable energy consumption on $\mathrm{CO} 2$ emissions, some authors have stressed some key features, for example Koengkan and Fuinhas (2017) examined the impact of renewable energy consumption on emissions of CO2 in ten South American countries in the period from 1980 to 2012 using PARDL in the form of UECM. The authors found that the consumption of renewable energy has a negative impact on -0.0420 in the short run. Indeed, this negative impact is related to the globalisation process that exerts a positive effect on economic growth and consequently on renewable energy consumption and new investment in green technology and therefore on emissions of $\mathrm{CO} 2$.

Fuinhas et al. (2017) studied the effect of renewable energy policies on $\mathrm{CO} 2$ emissions, for which a panel of ten Latin American countries was examined for the period from 1991 to 2012 and a PNARDL model was used as the method. The authors have a different opinion about this effect and confirm that this decrease is related to the efficiency of renewable energy policies that encourage the introduction of alternative energy sources in the energy mix. Other authors share this vision (e.g., Bilgili et al., 2016; Shafiei and Salim, 2014; Akella et al., 2009). The second approach in the literature suggests that the consumption of renewable energy causes an increase in emissions (e.g., Koengkan et al., 2018a; Apergis and Payne, 2014; Sadorsky, 2009). Therefore, some authors have stressed some key features. For example, Koengkan et al. (2018a) studied the influence of hydroelectricity consumption on emissions on $\mathrm{CO} 2$ in seven South American countries from 1966 to 2014. The authors found that the use of this kind of energy increases emissions by 0.0593 in the long run. Indeed, this effect occurs in the first few years after a reservoir is created, when the trees that have died in the process of flooding release $\mathrm{CO} 2$ in their decomposition process, and from turbines and spillways during the process of energy generation. These emissions can be compared with those generated from fossil fuels.

Nevertheless, Apergis and Payne (2014) studied the determinants of renewable energy consumption for a panel of seven Central American countries from 1980 to 2010 using the FMOLS model as the method. The authors found that the positive impact of renewable energy consumption on $\mathrm{CO} 2$ emissions is due to several legal and institutional barriers that do not encourage the expansion of renewable energy, as well as the increase in the use of renewable energy sources. Sadorsky (2009) has a different opinion, where, according to this author, the positive impact of renewable energy on $\mathrm{CO} 2$ emissions is attributable to the lack of financial incentives that do not encourage the development of renewable energy technologies and consequently the consumption of green energy.

\section{Data and Methodology}

Section 3 is divided into two parts: (3.1) presents the data and variables that will be used, and (3.2) describes the adopted methodological strategy that will be applied in this investigation. 
Notes ( $\dagger$ ): According to World Bank Open Data (2019), the CO2 emissions of these emissions come largely from energy production and use, which accounts for the largest share of greenhouse gases, associated with global warming. Moreover, anthropogenic $\mathrm{CO} 2$ emissions result primarily from the consumption of fossil fuels and cement manufacturing. Therefore, in combustion, different fossil fuels release different amounts of carbon dioxide for the same level of energy use, where oil releases about $50 \%$ more carbon dioxide than natural gas, and coal releases about twice as much. Moreover, cement manufacturing releases about half a metric ton of carbon dioxide for each metric ton of cement produced. The data for $\mathrm{CO} 2$ emissions includes gases from the burning of fossil fuels and cement manufacture but excludes emissions from land use such as deforestation.

Notes $(\$)$ : The renewable energy consumption $(\mathrm{kWh})$ per capita is the multiplication of total energy consumption per capita in $\mathrm{kWh}$ by renewable energy consumption ( $\%$ of total final energy consumption). Both variables were retrieved from World Bank Open Data (2019). The option to use this variable was taken because there is no data from the consumption of renewable energy in $\mathrm{kWh}$. Costa Rica, Dominican Republic, Ecuador, El Salvador, Guatemala, Haiti, Mexico, Nicaragua, Panama, Paraguay, Peru, Uruguay, and Venezuela (RB). The use of time-series between 1990 and 2014 is due to the availability of data until 2014 for the variable carbon dioxide emissions in kilotons (kt) in all countries selected in World Bank Open Data (2019).

registered rapid growth in the consumption of renewable and non-renewable energy; (b) they have experimented a rapid process of economic growth; (c) in the last three decades, the CO2 emissions from the LAC countries have more than doubled; (d) the existence of a complete database was the main criteria for choosing the countries from the LAC region, and (e) they have experienced a rapid process of energy transition. The variables which were chosen to perform this investigation are:

- Carbon dioxide emissions $(\mathbf{C O 2})^{\dagger}$ in kilotons $(\mathrm{kt})$ per capita from the burning of fossil fuels and the manufacture of cement. These include carbon dioxide produced during the consumption of solid, liquid and gas fuels and gas flaring retrieved from World Bank Open Data (2019); consumption from biomass, hydropower, solar, photovoltaic, wind, wave and waste in $(\mathrm{kWh})$ per capita divided by the fossil fuel consumption from oil, gas and coal sources in $(\mathrm{kWh})$ per capita. The use of renewable energy was created with data retrieved from World Bank Open Data (2019), and the consumption of fossil energy source was retrieved from the same place;

Gross domestic production (GDP) in constant (2010 US\$) per capita retrieved from World Bank Open Data (2019);

of the country's total trade - the sum of exports plus imports - to the country's gross domestic product, retrieved from World Bank Open Data (2019); defined by national statistical offices, retrieved from World Bank Open Data (2019).

The variables CO2, GDP, and RET were transformed into per capita values with the total population of each cross. The per capita value allows disparities to be controlled for in population Furthermore, this investigation used the GDP in constant 2010 US\$ instead of the constant LCU. The initial estimations using constant 2010 US\$ presented slightly different results from when constant LCU was used. Table 1 shows the summary statistics of variables. 
Table 1. Summary statistics of variables

\begin{tabular}{lccccc}
\hline \multirow{2}{*}{ Variables } & \multicolumn{5}{c}{ Descriptive Statistics } \\
\cline { 2 - 6 } & Obs. & Mean & Std. Dev. & Min & Max \\
\hline LnCO2 & 450 & -6.7708 & 1.3936 & -11.7542 & -4.8785 \\
LnGDP & 450 & 8.4056 & 0.7719 & 6.4956 & 9.5943 \\
LnRET & 450 & 1.4205 & 2.9823 & -2.5181 & 11.6017 \\
LnTRADE_OPEN & 450 & 3.9871 & 0.4605 & 2.6212 & 5.1161 \\
LnURBA & 450 & 4.1945 & 0.2405 & 3.3502 & 4.5532 \\
DLnCO2 & 432 & 0.0203 & 0.1198 & -0.8107 & 1.0799 \\
DLnGDP & 432 & 0.0203 & 0.0349 & -0.1462 & 0.1503 \\
DLnRET & 432 & -0.0352 & 0.5665 & -5.1635 & 3.5353 \\
DLnTRADE_OPEN & 432 & 0.0090 & 0.1095 & -0.5580 & 0.6475 \\
DLnURBA & 432 & 0.0078 & 0.0068 & 0.0001 & 0.0453 \\
\hline
\end{tabular}

Notes: Obs. denotes the number of observations; Std. Dev. denotes the Standard Deviation; Min. and Max. denote Minimum and Maximum, respectively; (Ln and DLn) denote variables in natural logarithms and first-differences of logarithms, respectively.

Moreover, we should stress that they are already in their natural logarithms (see prefix "Ln"). Indeed, there is a logical explanation for using these variables in our model. Therefore, the increased effect of greenhouse gas (GHG) concentrations on global temperatures and the earth's climate have consequences for ecosystems, human settlements, agriculture and other socioeconomic activities (UNEP, 2001). GHG emissions have increased because CO2 emissions are still growing in many countries, despite some progress achieved in decoupling $\mathrm{CO} 2$ emissions from GDP growth (OECD Environment Directorate, 2008). In the LAC countries it is no different, with emissions of CO2 growing almost ten-fold since the 1970s reaching 1,912,531.50 million kilotons in 2014 (see Figure 1 in Appendix). Therefore, CO2 emissions are a better indicator of environmental performance because they are the major contributor to the greenhouse effect (OECD Environment Directorate, 2008). The consumption of energy is the main contributor to $\mathrm{CO} 2$ emissions, where in the LAC countries the energy sector accounts for approximately $35 \%$ of total emissions in 2010, as cited by Hollanda et al. (2016). This is the justification for our study using $\mathbf{C O 2}$ as the dependent variable.

As mentioned before, a relationship exists between $\mathrm{CO} 2$ emissions and GDP growth and this relationship is due to economic growth raising standards of living in most countries; it was also responsible for the increase in $\mathrm{CO} 2$ emissions and reductions in natural resources (Mardani et al., 2019). In the Latin American countries, the GDP per capita has registered average annual growth rates of approximately $3.0 \%$, (see Figure 2 in Appendix). As a consequence of this growth in the Latin American countries, electric power consumption (kWh per capita) in the region has followed a similar path (see Figure 3 in Appendix), where the use of energy grew by approximately 5.4\%, as stated before by Balza et al. (2016). For this reason, this investigation opted to use the GDP as an independent variable.

Indeed, this increase in GDP per capita results from several economic reforms such as trade liberalisation in the last forty years that subsequently influenced the investment and consumption of energy and the $\mathrm{CO} 2$ emissions in the Latin American region. For this reason, this investigation opted to use TRADE OPEN as an independent variable. Beyond trade openness, the urbanisation process has also been shown to have a negative influence on the quality of the environment. The global level of urbanisation went from $39.1 \%$ in 1980 to $52.0 \%$ in 2011 , mainly due to the gradual transition of rural population to urban areas. In Latin America, urbanisation grew from $25 \%$ in the 1920 s to $48.9 \%$ in the 1960 s. During the period ranging from 1975 to 2007 , the urbanisation rate grew $0.78 \%$, and it is expected to grow $0.36 \%$ between 2007 and 2025 . The rapid growth of urbanisation in Latin America is mainly linked to the introduction of new agricultural technologies, and with the industrialisation process influenced by trade liberalisation, which led to a restructuring of rural economies and economic development in most Latin American countries. Indeed, as the urbanisation process could be linked to both economic 
development and energy consumption, and consequently, to the increase in $\mathrm{CO} 2$ emissions, it is natural that the relationship between $\mathrm{CO} 2$ emissions and urbanisation should receive a considerable degree of attention in this investigation. This is the justification for our study opting to use URBA as an independent variable.

Moreover, the use of renewable energy represented $35 \%$ of the total energy consumption in 2013, and investment in renewable energy grew by 13\% between 2000 and 2013, as cited before by Koengkan (2018a) and Koengkan et al. (2019a). This increase in the consumption of renewable energy is an indicator of the energy transition process, as mentioned by Hauff et al. (2014). Therefore, to identify the effect of the energy transition on environmental degradation, we opted to use the ratio of renewable energy consumption to fossil fuel consumption. This ratio is obtained by dividing the consumption of renewable energy by the consumption of fossil fuels. This ratio captures the progression of the consumption of renewable energy to the consumption of fossil fuels over time. Moreover, this method for capturing this progression was used before by Fuinhas et al. (2019) to capture the progress of the weight of oil production to consumption of oil consumption over time. For this reason, RET is used as an independent variable in this investigation.

\subsection{Methodology}

The PARDL model in the form of UECM will be used as our central model estimation for the realisation of this investigation. Therefore, as stated by Koengkan et al. (2019f), this model was introduced by Granger (1981), and by Engle and Granger (1987), and later upgraded by Johansen and Juselius, (1980) who introduced cointegration techniques that permit the identification of a long-run relationship between non-stationary series and their parametrisation into an error correction model (UECM) (Nkoro and Uko, 2016). Moreover, Koengkan et al. (2019f) add that this model also permits decomposition of the total effects of variables into their short- and long-run components.

Despite this, this model was utilised in this investigation because in the panel with the long time span, that is "macro panels", there is generally the presence of cointegration between the variables as well as endogeneity. Nevertheless, if one does not use the appropriate econometric techniques in order to deal with the cointegration and endogeneity problem, it can lead to estimation errors and misinterpretation of results. Therefore, in order to resolve this problem, the PARDL model is the best candidate due to its robust econometric estimation technique that reduces the effects of cointegration and endogeneity. This model also presents other qualities or advantages that were approached by Koengkan et al. (2019f), such as the capacity to produce efficient parameter estimates with relatively small samples, or the capacity to carry out analysis even in the presence of $\mathrm{I}(0)$ and $\mathrm{I}(1)$ variables and so on. All these qualities or advantages lead this methodology to be applied in several areas in the literature. It can be seen in Figure 7, which shows the applications of PARDL models in the literature. 


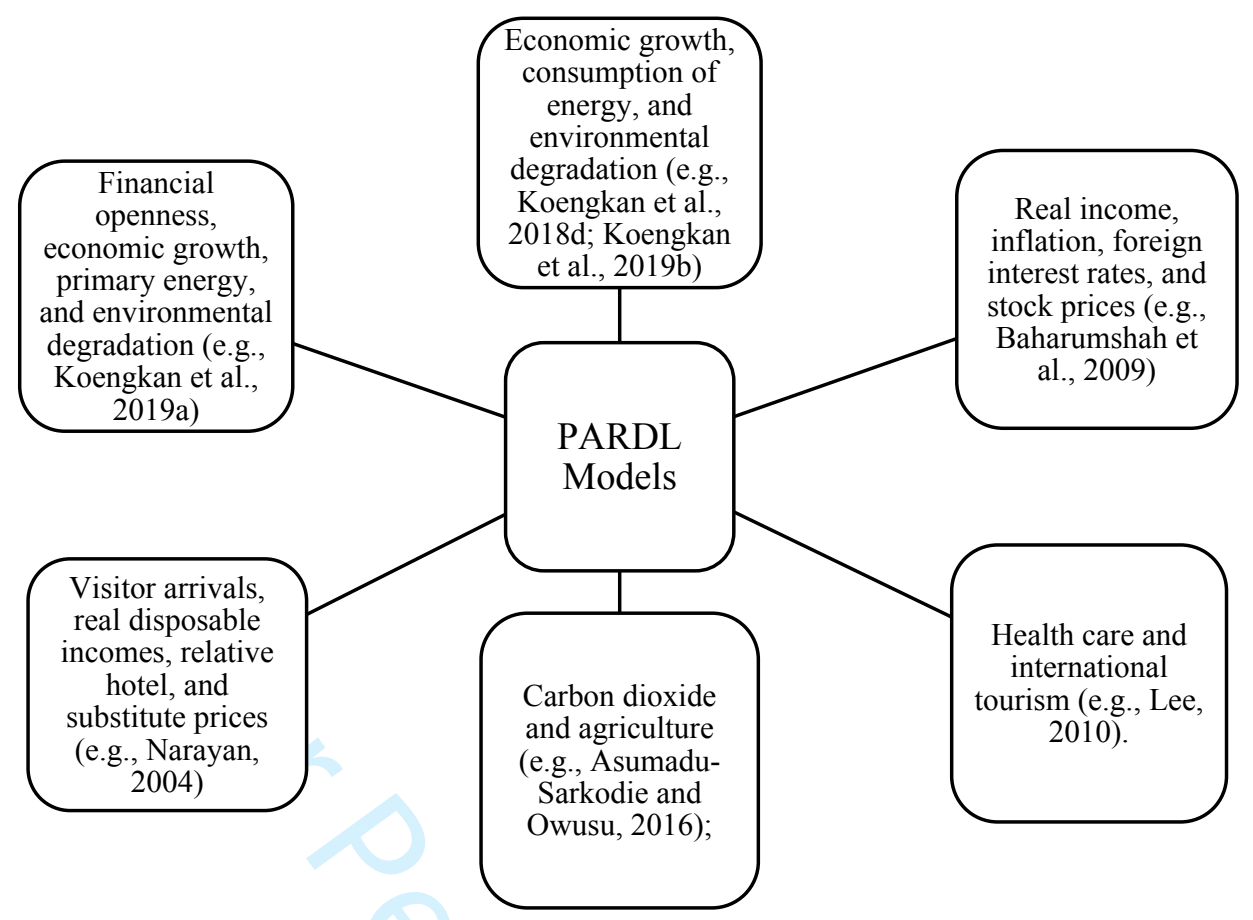

Figure 7. Applications of PARDL models in the literature

Then, the general PARDL model in the form of UECM follows the specification of Equation (1):

$$
\begin{aligned}
& \operatorname{DLnCO}_{i t}=\alpha_{i t}+\beta_{1 i 1} D \operatorname{LnGDP} P_{i t-1}+\gamma_{1 i 2} \\
& +\operatorname{DLnRET}_{i t-1}+\gamma_{1 i 3}+\text { DLnTRADE_OPEN } \text { L }_{i t}+\gamma_{1 i 4}+\operatorname{DLnURBA}_{i t-1}+\mathrm{Li}_{\mathrm{i}} \\
& +\gamma_{1 i 2} \operatorname{LnGDP} P_{i t-1}+\gamma_{1 i 3} \operatorname{LnRET} T_{i t-1}+\gamma_{1 i 4} \operatorname{LnTRADE} \text { OPEN }_{i t-1} \\
& +\gamma_{1 i 5} \operatorname{Ln} U R B A_{i t-1}+\varepsilon_{1 i t}
\end{aligned}
$$

where $\alpha_{i}$ represents the intercept, $\beta_{i k}$ and $\gamma_{i k}$, with $\mathrm{k}=1, \ldots, 5$, denote the estimated parameters and $\varepsilon_{i t}$ is the error term. The prefixes "Ln" and "DLn" denote natural logarithms and first-differences. Moreover, it is worth remembering that was used a parsimonious model of Equation (1). That is, statistically insignificant variables were removed from the model (e.g., DLnURBA) in the prior model's regressions (see Equation 1). Therefore, the parsimonious PARDL model in the form of UECM follows the specification of Equation (2):

$$
\begin{aligned}
& \operatorname{DLnCO}_{i t}=\alpha_{i t}+\beta_{1 i 1} D \operatorname{LnGDP} P_{i t-1}+\gamma_{1 i 2} \\
& +\operatorname{DLnRET}_{i t-1}+\gamma_{1 i 3}+\text { DLnTRADE_OPEN } N_{i t-1}+\operatorname{LnCO}_{i t-1}+\gamma_{1 i 2} \\
& \operatorname{LnGDP}_{i t-1}+\gamma_{1 i 3} \operatorname{LnRET}_{i t-1}+\gamma_{1 i 4} \operatorname{LnTRADE}_{-} O P E N_{i t-1} \\
& +\gamma_{1 i 5} \operatorname{LnURB} A_{i t-1}+\varepsilon_{1 i t}
\end{aligned}
$$

where $\alpha_{i}$ represents the intercept, $\beta_{i k}$ and $\gamma_{i k}$, with $\mathrm{k}=1, \ldots, 5$, denote the estimated parameters and $\varepsilon_{i t}$ is the error term. The prefixes "Ln" and "DLn" denote natural logarithms and first-differences. Additionally, the PARDL model approach allows the use of a combination of variables I(0) and I(1).

Therefore, before the PARDL model estimation, it is mandatory to examine the characteristics of the variables, which include the cross-section and time series, as well as to ascertain the presence of specificities which, if not considered, may produce inconsistent and incorrect results. 
To this end, the preliminary and specification tests will be made before estimating the model of interest. The subsequent tests are thus executed:

(i) Preliminary tests: (a) variance inflation factor (VIF) to verify the presence of multicollinearity among the variables; (b) cross-section dependence (CSD) test (Pesaran, 2004); (c) Pesaran's CIPS test (Pesaran, 2007) to find the presence of unit roots; (d) the Hausman test to identify heterogeneity, i.e., whether the panel has random effects (RE) or fixed effects (FE) and; (e) mean group (MG), fixed effects (FE), and pooled mean group (PMG) estimators;

(ii) Specification tests: (f) modified Wald test (Greene, 2002) to check for the existence of group-wise heteroscedasticity; (g) Wooldridge test (Wooldridge, 2002) to check the presence of serial correlation; (h) Frees's test for cross-sectional independence; and (i) the Breusch and Pagan Lagrangian multiplier test (Breusch and Pagan, 1980) for cross-sectional correlation in the fixed-effects model.

The estimation and testing procedures are carried out using Stata 15.0.

\section{Empirical results}

As previously explained in the introduction, this section will present the empirical results of preliminary and specification tests as well as the outcomes of PARDL model estimation. The VIF and CSD-tests inform on the presence of multicollinearity, while the second group of tests refers to the presence of cross-sectional dependence. The results of VIF-test indicate that the presence of multicollinearity is not a concern in the estimation, given the low VIF and mean VIF values registered, which are lower than the usually accepted benchmark of 10, in the case of the VIF values, and 6 in the case of the mean VIF values. Regarding the CSD-test, we see that the null hypothesis is rejected in all variables in logarithms and in the variables in first-differences, such as DLnY, DLnRET, DLnTRADE_OPEN, and DLnURBA leading us to the conclusion that there is a correlation between the series across countries in these variables. In Table 2 below, we can see the results of VIF and CSD-tests, both in the first-differences and natural logarithms. 
Table 2. VIF and CSD tests

\begin{tabular}{|c|c|c|c|c|c|c|}
\hline Variables & VIF & $1 / \mathrm{VIF}$ & \multicolumn{2}{|c|}{ CD-test } & Corr & Abs (corr) \\
\hline $\mathrm{LnCO2}$ & \multicolumn{2}{|c|}{ n.a. } & 33.23 & $* * *$ & 0.537 & 0.585 \\
\hline LnGDP & 3.54 & 0.2827 & 43.42 & $* * *$ & 0.702 & 0.845 \\
\hline LnRET & 1.11 & 0.9006 & 5.38 & $* * *$ & 0.087 & 0.373 \\
\hline LnTRADE_OPEN & 1.18 & 0.8499 & 18.06 & $* * *$ & 0.292 & 0.498 \\
\hline LnURBA & 3.66 & 0.2734 & 60.56 & $* * *$ & 0.979 & 0.979 \\
\hline Mean VIF & \multicolumn{2}{|c|}{2.37} & & & & \\
\hline DLnCO2 & \multicolumn{2}{|c|}{ n.a. } & 0.26 & & 0.004 & 0.172 \\
\hline DLnGDP & 1.04 & 0.9583 & 17.70 & $* * *$ & 0.292 & 0.319 \\
\hline DLnRET & 1.02 & 0.9837 & 2.08 & $* *$ & 0.034 & 0.209 \\
\hline DLnTRADE_OPEN & 1.01 & 0.9887 & 15.45 & $* * *$ & 0.255 & 0.279 \\
\hline DLnURBA ${ }^{-}$ & 1.03 & 0.9725 & 26.24 & $* * *$ & 0.433 & 0.562 \\
\hline Mean VIF & \multicolumn{2}{|c|}{1.02} & & & & \\
\hline
\end{tabular}

Indeed, the VIF-test helps us to understand the degree of multicollinearity which may be present in our model and which can lead to problems in estimation. The null hypothesis of CSD test is the presence of CSD in all variables. However, in the presence of CSD, it is necessary to assess the order of integration of the variables. In order to do this, the Pesaran (2007) Panel Unit Root test (CIPS) was used. This test is robust in the presence of CSD, and we did not opt to use the first-generation test because it is inefficient in the presence of CSD. The null hypothesis of Pesaran's CIPS is that all series are stationary I(1). The results of this test can be seen in Table 3 below.

Table 3. Unit root test.

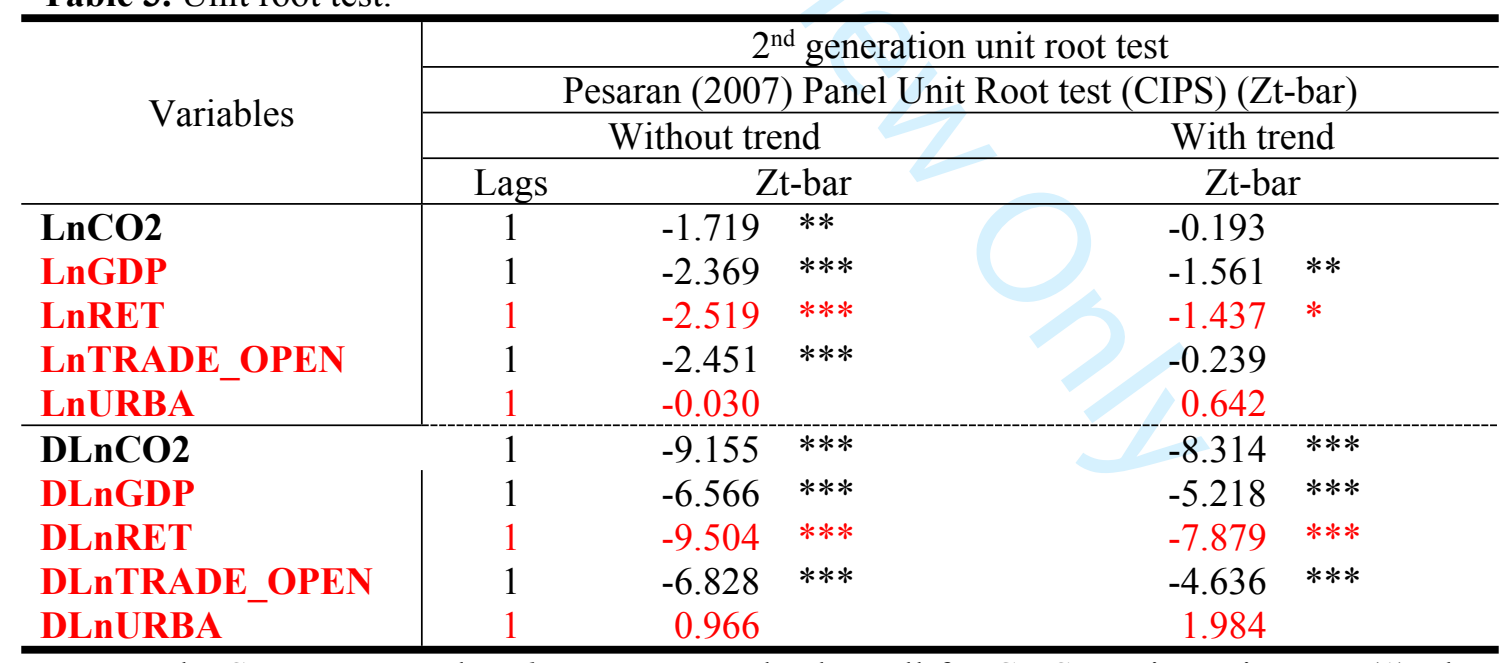

Notes: The Stata command multipurt was used; The null for CIPS test is: series are I(1); the lag length (1) and trend were used in this test; ***, **, and * denote statistically significant at $1 \%, 5 \%$, and $10 \%$ levels respectively; (Ln and DLn) denote variables in natural logarithms and first-differences of logarithms respectively.

The results from the Pesaran CIPS test show that none of the variables seems to be I(2), although they show that some of them may be on the borderline between the I( 0$)$ and I(1) order of integration (i.e., in the first-differences with and without trend, except the variables DLnTRADE_OPEN with trend, and DLnURBA without trend and with trend, and in some variables in the natural logarithms, such as LnCO2, LnGDP, LnRET, 
LnTRADE_OPEN without trend, and also LnGDP without trend and LnRET without trend and with trend seem to be stationary). After the realisation of the unit root test, the next step is to assess the presence of individual effects in the model. To this end, the Hausman test, comparing random (RE) and fixed effects (FE), was used. The null hypothesis of this test is that the difference in coefficients is not systematic, (i.e., random effects are the most suitable estimator). The Hausman test indicates that the null hypothesis should be rejected (chi2 $(9)=91.92$, statistically significant at $1 \%$ level) and that a fixed-effects model is the most appropriate for this analysis.

To assess the presence of heterogeneity/homogeneity in the panel, the MG, PMG, and FE techniques were used. The MG estimator developed by Pesaran and Smith (1995) calculates the average of coefficients of all individuals, with no restrictions regarding the homogeneity of the short and long run. Nevertheless, the PMG estimator created by Pesaran et al. (1999) permits for differences in error variances, short-run coefficients, speed of adjustment and intercepts (i.e., these parameters may be country-specific), but it imposes a homogeneity restriction on the long-run coefficients (i.e., they should be equal across countries). Formerly, the PMG estimator can combine the "pooling" from the FE estimator with the "averaging" from the MG estimator. However, in the presence of panel homogeneity in the long run, this estimator is more efficient than the MG estimator. Table 4 below shows the outcomes for the three specifications (e.g., MG vs PMG; PMG vs FE; and MG vs FE).

Table 4. Hausman test

\begin{tabular}{ccc}
\hline MG vs PMG & PMG vs FE & MG vs FE \\
\hline Chi2 $(9)=213.12 * * *$ & $\operatorname{chi} 2(9)=-93.69$ & $\operatorname{chi} 2(9)=229.48 * *$ \\
\hline
\end{tabular}

Notes: *** denotes statistically significant at the $1 \%$ level; Hausman results for $\mathrm{H}_{0}$ : difference in coefficients not systematic; the Stata commands xtpmg, and Hausman (with the options, alleqs constant) were used.

Results for the above-mentioned specifications (e.g., MG vs PMG; PMG vs FE; and MG vs FE) suggest that the panel is homogeneous and that the FE is the most appropriate estimator. Before model estimation, the following specification tests are performed: (f) the Modified Wald test; (g) the Wooldridge test; (h) Frees's test, and (i) the Breusch and Pagan Lagrangian multiplier test. Results are presented in Table 5.

Table 5. Specification tests

\begin{tabular}{ccccc}
\hline \multirow{2}{*}{ Statistics } & Modified Wald test & Wooldridge test & $\begin{array}{c}\text { Frees } \\
\text { test }\end{array}$ & $\begin{array}{c}\text { Breusch and Pagan } \\
\text { Lagrangian } \\
\text { Multiplier test }\end{array}$ \\
\cline { 2 - 5 } & $\begin{array}{c}\mathrm{chi}(18)= \\
2757.02 * * *\end{array}$ & $\begin{array}{c}\mathrm{F}(1,17)= \\
48.813 * * *\end{array}$ & 0.352 & n.a. \\
\hline
\end{tabular}

Notes: $* * *$ denotes statistically significant at the $1 \%$ level; $\mathrm{H}_{0}$ of Modified Wald test: sigma(i)^2 $=\operatorname{sigma}^{\wedge} 2$ for all $\mathrm{i} ; \mathrm{H}_{0}$ of Wooldridge test: no first-order autocorrelation; $\mathrm{H}_{0}$ of Frees' test: residuals are not correlated; $\mathrm{H}_{0}$ of Breusch and Pagan Lagrangian Multiplier test: no dependence between the residuals; n.a. denotes not available.

The results of the specification test indicate rejection of the null hypothesis of modified Wald and Wooldridge tests at the 1\% level, indicating the presence of heteroscedasticity and first-order autocorrelation. Moreover, it cannot reject the null hypothesis of Frees's test, indicating the non-presence of correlation. Regarding the Breusch and Pagan Lagrangian multiplier test, it could not compute it because the 
correlation matrix of residuals was singular. This situation occurs because the number of crosses under study is less than the number of years.

After the realisation of preliminary and specification tests, the model regression can be made. Therefore, three estimations were computed in this model, the FE, FE robust standard errors (FE Robust), and FE Driscoll and Kraay (FE D.-K.). Indeed, the FE D.$\mathrm{K}$. was used due to the specification tests results, to deal with the presence of heteroscedasticity and first-order autocorrelation. This estimator can produce standard errors robust to the phenomena that were found in the sample errors. The regression dummy and shift-dummy variables were included in the model. Moreover, it is worth remembering that the parsimonious model was estimated. That is, the insignificant variables (e.g., DLnURBA) from previous regressions of the general model were removed (see Equation 2).

These dummy variables were added to the model because, during the period of analysis, the LAC countries suffered several shocks that, if not considered, could have produced inaccurate results that could lead to misinterpretations. Thus, the dummy and shift-dummy variables that were added to the regression are the following: IDECUADOR_1994 (Ecuador, 1994); SDHAITI_1993_1995 (Haiti, years between 1993 and 1995); IDPANAMA_1995 (Panama, 1995); SDPANAMA_1996_1997 (Panama, years between 1996 and 1997);IDDOMINICAN REPUBLIC_ 2007, and IDGUATEMALA_2014 (Guatemala, 2014). Indeed, IDECUADOR_1994 represents a break in the GDP of Ecuador in 1994. This break can be justified by low economic growth between 1993 and 1995 (Jácome, 2004); SDHAITI_1993_1994 represents two breaks in the GDP of Haiti between 1993 and 2014. These breaks can be justified by Operation Uphold Democracy that was a military intervention designed to remove the military regime installed by the 1991 Haitian coup d'état that overthrew the elected President JeanBertrand Aristide. The operation was effectively authorised in 1994 (The Carter Center, 1994); IDPANAMA_1995 represents a break in the GDP of Panama in 1995. This break can be justified by a decrease in economic activity, where the GDP of Panama grew just 1.8\% in 1995 (World Bank Open Data, 2019); SDPANAMA_1996_1997 represents two peaks in the GDP of Panama between 1996 to 1997. These peaks can be justified by an increase in economic activity, where the GDP of Panama in 1996 grew 4.1\%, and in 1997, 6.5\% (World Bank Open Data, 2019); IDDOMINICAN REPUBLIC_2007 represents a peak in the GDP of the Dominican Republic in 2007. These peaks can be justified by an increase in economic activity, where the GDP of the Dominican Republic in 2007 grew 7.4\% (World Bank Open Data, 2019); and IDGUATEMALA_2014 represents a peak in the GDP of Guatemala in 2014. This peak can be justified by the acceleration of the country's economic activity in 2014, where the GDP of the country grew $4.2 \%$ (World Bank Open Data, 2019).

Therefore, these peaks and breaks impacted the renewable energy transition and consequently, the emissions of $\mathrm{CO} 2$ in these countries. Table 6 displays the short-run impacts, the model speed of adjustment, and the computed long-run elasticities.

Table 6. Elasticities, short-run impacts, impacts, and adjustment speed (controlling for shocks)

\begin{tabular}{|c|c|c|c|c|}
\hline \multirow{2}{*}{ Independent variables } & \\
\hline & \multicolumn{2}{|c|}{ FE } & \multirow{2}{*}{$\begin{array}{c}\text { ariable (DLI } \\
\text { FE Robust } \\
* * *\end{array}$} & \multirow{2}{*}{$\frac{\text { FE D.-K. }}{* * *}$} \\
\hline Constant & -6.7014 & $* * *$ & & \\
\hline & Shocks & & & \\
\hline IDDOMINICAN_REPUBLIC_2007 & 0.2582 & $* * *$ & $* * *$ & $* * *$ \\
\hline IDECUADOR $1 \overline{994}$ & -0.5077 & $* * *$ & $* * *$ & $* * *$ \\
\hline IDGUATEMĀLA 2014 & 0.2765 & $* * *$ & $* * *$ & $* * *$ \\
\hline SDHAITI 19931995 & -0.3793 & $* * *$ & $* * *$ & * \\
\hline
\end{tabular}




\begin{tabular}{|c|c|c|c|c|}
\hline IDPANAMA_1995 & -0.4141 & $* * *$ & $* * *$ & $* * *$ \\
\hline SDPANAMA 1996 1997 & 0.1764 & $* * *$ & $* * *$ & $* * *$ \\
\hline \multicolumn{5}{|c|}{ Short-run } \\
\hline DLnGDP & 0.4465 & $* * *$ & & $*$ \\
\hline DLnRET & -0.0675 & $* * *$ & $* * *$ & $* * *$ \\
\hline DLnTRADE_OPEN & 0.0918 & $* *$ & & \\
\hline \multicolumn{5}{|c|}{ Long-run } \\
\hline $\operatorname{LnGDP}(-1)$ & 0.2361 & $* * *$ & $* * *$ & $* * *$ \\
\hline LnRET (-1) & -0.0313 & $* * *$ & $* * *$ & $* * *$ \\
\hline LnTRADE_OPEN (-1) & 0.0446 & $*$ & & $* *$ \\
\hline $\operatorname{LnURBA}(-\overline{1})$ & 0.3030 & $* * *$ & $* *$ & $* *$ \\
\hline \multicolumn{5}{|c|}{ Speed of adjustment } \\
\hline ECM & -0.4909 & $* * *$ & $* * *$ & $* * *$ \\
\hline
\end{tabular}

Notes: $* * * * *$ and $*$ denote statistically significant at the $1 \%, 5 \%$ and $10 \%$ levels, respectively; The ECM denotes the coefficient of the variable LnCO2, lagged once; (Ln and DLn) denote variables in natural logarithms and first-differences of logarithms respectively.

The results from Table 6 indicate that the economic growth and trade openness in the short and long run and also urbanisation in the long run increase the $\mathrm{CO} 2$ emissions. However, the ratio of renewable energy that is a proxy of energy transition decreases these emissions in the short and long run.

\section{Discussion}

The analysis of the effect of the renewable energy transition on CO2 emissions in the Latin American \& Caribbean countries extends the approach about this topic. Indeed, the empirical results from the PARDL model indicate that economic growth in both the short and long run has a positive impact of 0.4465 and 0.2361 , respectively and trade openness in the short and long run has a positive impact of 0.0918 and 0.0446 , respectively, and urbanisation in the long run also has a positive impact of 0.3030 on $\mathrm{CO} 2$ emissions. That is to say, economic growth, trade openness and urbanisation contribute to the increase in $\mathrm{CO} 2$ emissions. However, the ratio of renewable energy, which is a proxy of the renewable energy transition, has a negative impact on emissions of $\mathrm{CO} 2$ in the short and long run of -0.0675 and -0.0313 respectively. That is, the process of the energy transition can mitigate environmental degradation in LAC countries. Concerning the ECM term, it is negative and statistically significant at the $1 \%$ level, and the statistical significance at the $1 \%$ level of the dummy and shift-dummy variables supports the decision to include them in the model.

Then, based on these results, we can pose the following questions in order to help us explain the possible reasons for these phenomena that were found in our analysis. What are the possible explanations for the capacity of economic growth, trade openness, and urbanisation increasing emissions of $\mathrm{CO} 2$ in the LAC region? What are the possible explanations for the capacity of renewable energy transition mitigating these emissions?

The possible explanation for the positive effect of economic growth on $\mathrm{CO} 2$ emissions in the LAC region is related to fossil fuel sources being the primary inputs for industry and agriculture, which consequently encourages economic growth and emissions of CO2 in the LAC countries (Mirza and Kanwal, 2017). However, another possible explanation for this impact is that an increase in economic activity will lead to an increase in the CO2 emissions at high levels of income due to the increase in manufacturing industries in these countries. In other words, in the early stages of development of LAC economies, the CO2 emissions would decrease. However, these emissions increase later after the economic growth exceeds the threshold parameter. Therefore, in the period of economic boom, households and companies will have more income and consequently will increase the consumption of energy from electric devices, transportation and appliances, among others, which will contribute to an increase in CO2 emissions (Aye and Edoja, 2017). There is another explanation for this positive impact. According to Omri et al. 
(2014), trade openness, economic capitalisation, and the development of infrastructure in LAC countries are responsible for this positive impact, where these factors have a positive influence on investment, economic activity and consequently on the consumption of energy.

The possible explanation for the positive effect of trade openness, which is a proxy of globalisation, on $\mathrm{CO} 2$ emissions in LAC region is related to the increase in international trade from liberalisation and that consequently transfers dirty industries from developed countries to developing ones for the sake of tax incentives, inevitably bringing dirty industries (Ertugrul et al., 2016). Moreover, Kukla-Gryz (2009), adds that the demand for a cleaner environment increases with raises in per capita income. This increase encourages the dirty industries in developed countries to look for other countries with lower environmental regulations. The dirty industries in developing economies apply low environmental standards in order to ensure a competitive advantage. This causes the carbon-intensive productions to flow from developed countries to developing ones (Ertugrul et al., 2016). Therefore, the CO2 emissions in the developing countries follow an increasing trend, while in developed countries these emissions decline with more environmental regulations. This phenomenon, according to Kuik and Gerlagh (2003), is called carbon leakage.

Moreover, trade liberalisation with its unrestricted regulations encourages an increase in the number of companies producing pollution-intensive export goods and an increase in the volume of dirty-goods related to foreign direct investment (FDI) (Kirkpatrick and Scrieciu, 2008).

Indeed, the net effect of trade liberalisation on $\mathrm{CO} 2$ emissions is ambiguous in general. The explanation of this impact depends on the net effect of the scale effect (e.g., Ertugrul et al., 2016; Farhani et al., 2014). According to Ertugrul et al. (2016), the scale effect means that trade liberalisation leads to economic activity and consequently higher rates of $\mathrm{CO} 2$ emissions, where greater production induced by economic growth consequently leads to more energy consumption. Therefore, the positive impact of trade openness on $\mathrm{CO} 2$ emissions reveals that the process of globalisation by trade liberalisation in LAC countries is not sufficient to bring more investment, which encourages R\&D in energy-efficient technologies, and equipment that reduces the consumption of energy from non-renewable energy sources by households and firms.

The possible explanation for the positive effect of urbanisation on $\mathrm{CO} 2$ emissions in the LAC region is related to the rapid economic growth influenced by the implementation of the neoliberal economic model which has taken place during the process of the "Washington consensus", as mentioned before. That is, the rapid economic growth caused by neoliberal reforms encouraged the process of industrialisation in the LAC region and the urbanisation that consequently impacted the consumption of energy and CO2 emissions (Koengkan, 2018b). Another possible explanation for this effect is related to the urbanisation process which influenced the popularity of household appliances and the pursuit of private transport in the LAC region. The increase in this popularity has consequences for the consumption of energy in the region (Koengkan, 2018b). Moreover, Shahbaz et al. (2015a) add that the movement of people from rurals to urban areas caused by economic development has a positive impact on the economy, where this movement makes an economic transition from agriculture to an industrialisation economy and consequently increases the energy demand and environmental degradation.

Moreover, the possible explanation for the ratio of renewable energy, which is a proxy of the renewable energy transition, reducing emissions of $\mathrm{CO} 2$ is probably related to the technological efficiency of renewable energy that produces more clean energy with fewer emissions, as well as the increasing participation of renewable energy sources in the energy mix in these countries (Koengkan et al., 2019c). Indeed, these factors, according to Koengkan and Fuinhas (2017), are possibly related to the globalisation process in LAC countries, which exerts a positive impact on the factors of productivity and economic growth and consequently on the consumption of renewable energy and new investment in green technology. Shahbaz et al. (2015b) add that the liberalisation and competition brought by the process of globalisation increase the environmental regulation standards regarding investment in cleaner technology. Moreover, globalisation improves economic growth and welfare by reducing cross border restrictions on trade and investment with other countries. This reduction in border restrictions encourages foreign firms to set up new businesses or expand their existing ones using newer and more advanced technologies that reduce the consumption of fossil fuels and thereby lower their 
overall costs. This is likely to influence existing firms in the host country to adopt new methods of production, reducing the consumption of non-renewable energy sources and consequently $\mathrm{CO} 2$ emissions (Shahbaz et al., 2016).

This point of view is shared by Leitão (2014), who indicates that the globalisation process via trade openness leads developing countries to access efficient technologies from developed countries and consequently reduces the consumption of fossil fuels and emissions of CO2. Indeed, the technique effect is possible through trade openness, allowing developing countries to import advanced technologies from developed ones (Shahbaz et al., 2014). That is, the process of trade openness encourages the transfer of new technologies and helps technological progress and productivity improvement (Zahonogo, 2016). This idea is shared by Ertugrul et al. (2016), who indicate that the technique effect includes the impacts of transferred know-how and advanced technological production techniques on the environment. That is, through trade openness, environmentally friendly technologies and energy-efficient production technologies spread across countries. Therefore, transfer of renewable energy technologies has recently become more effective in mitigating emissions of CO2 in developing countries (Sebri and Ben-Salha, 2014). Another possible explanation is related to the efficiency of renewable energy policies that encourage the introduction of alternative energy sources in the energy mix. For example, in the LAC countries, the most effective policies are national renewable energy targets, which provide a clear indication about the intended level of development of alternative energy sources and the timeline envisioned by governments (Fuinhas et al., 2017).

Moreover, although the renewable energy transition can mitigate $\mathrm{CO} 2$ emissions, their impact is modest in the LAC region. This low capacity of renewable energy transition to mitigate emissions of $\mathrm{CO} 2$ could be linked to periods of low renewable energy production caused by droughts or climate change. In such cases, in order to attend to the energy demand, thermoelectrics powered by fossil fuels are activated. According to Koengkan et al., (2019f), renewable and fossil fuel energy sources substitute each other in the energy matrix in the Latin American countries.

\section{Conclusions and policy implications}

The main aim of this investigation is to analyse the impact of the renewable energy transition on CO2 emissions. Eighteen LAC countries were selected in a period between 1990 and 2014. This investigation opted to use PARDL as the methodology in the form of a UECM. The results from the preliminary tests indicated that the variables used have characteristics such as low-multicollinearity and cross-sectional dependence in the variables in the logarithms and first-differences, and in almost all cases, $\mathrm{I}(0) / \mathrm{I}(1)$ for all variables, and also the presence of fixed effects. Moreover, the specification tests indicated the presence of heteroscedasticity, first-order autocorrelation, and non-presence of correlation.

The results of the PARDL model indicated that economic growth in the short and long run, trade openness in the short and long run, and also urbanisation in the long run, have a positive impact on $\mathrm{CO} 2$ emissions. However, the ratio of renewable energy, which is a proxy of the renewable energy transition, has a negative impact on emissions of $\mathrm{CO} 2$ in both the short and long run. That is, the process of the renewable energy transition can mitigate environmental degradation in LAC countries. Moreover, these findings reveal that fossil fuel sources in these countries are the primary inputs for industry and agriculture, which consequently encourages economic growth and emissions of $\mathrm{CO} 2$. That is, the LAC countries are dependent on fossil fuels for growth. The process of trade openness in the LAC region is not sufficient to bring more investment and encourages R\&D in energy efficiency technologies and equipment, which reduces the consumption of energy from non-renewable energy sources by households and firms and consequently $\mathrm{CO} 2$ emissions. The process of urbanisation in the LAC region influences the industrialisation and popularity of household appliances and the pursuit of private transport in the LAC region and consequently increases the consumption of energy and $\mathrm{CO} 2$ emissions. Moreover, the process of the renewable energy transition in the LAC can mitigate the emissions of $\mathrm{CO} 2$ due to the efficiency of renewable energy technologies and renewable energy policies. However, the low capacity of the renewable energy transition to mitigate emissions of $\mathrm{CO} 2$ could be linked to periods of low renewable energy production caused by droughts or climate change. 
In such cases, in order to attend to the energy demand, thermoelectrics powered by fossil fuels are activated.

The process of investigation of this article is not free of limitations. The only limitation of this study was the limited data time due to the availability of data until 2014 for the variable carbon dioxide emissions in kilotons (kt) in all countries selected. Despite the limitations in the availability of data, the findings and results obtained from this investigation may have some important policy implications.

First, in order to reverse the increase in $\mathrm{CO} 2$ emissions, the LAC countries need to create mechanisms to diversify the nature of their exports and imports via trade openness. The aim should be the acquisition and development of new products, with higher technological efficiency which is capable of enhancing the production of renewable energy and reducing the consumption of fossil fuels and that consequently will reduce LAC countries' dependency on this kind of source. The diversification of exports and imports encourages the acquisition of new technologies. Therefore, the LAC countries should import more energy-efficient technologies from developed economies in order to reduce their energy consumption and improve their energy transition. However, this will not be possible if LAC countries develop mechanisms such as new tariff and non-tariff barriers on products and technologies that improve energy efficiency. This could reduce the prices of household appliances and equipment with high energy efficiency and encourage households and firms to purchase them. Indeed, energy-efficiency product standards and labelling are policy mechanisms that impact the consumption of fossil fuels and improve the process of the energy transition in the region.

The increase in energy efficiency (in systems related to the infrastructure, transport, buildings, and production sectors) is a priority of LAC governments that cannot be undermined. Other mechanisms should be implemented in the LAC countries due to their characteristics, for example, the decentralisation of energy production that improves the performance of the system, and the creation of official public banks with low-interest rates in order to finance projects in renewable energy. Policies should also be implemented that motivate private financial institutions to give special loan discounts to firms interested in investing in renewable energy technologies or in the purchase of technologies that increase energy efficiency and reduce environmental degradation and moreover, the design of more public policies aimed at motivating the everyday use of zero-emissions systems and technologies (e.g., renewable energy technologies). Therefore, these policies need to be implanted with the purpose of reducing the dependency of these countries on fossil fuels, reducing their environmental degradation, and promoting both economic growth and green development.

\section{Acknowledgements}

Funding: This study was funded by National Funds of the FCT - Portuguese Foundation for Science and Technology within the project UID/ECO/04007/2019, and NECE - Research Unit in Business Science and Economics, sponsored by the FCT and Higher Education, project UID/GES/04630/2019.

We are grateful to two anonymous reviewers for the remarks which improved the quality of our research.

\section{References}

Ahumada C., Andrews C.W., (1998). The Impact of Globalization on Latin American States: The Cases of Brazil and Colombia. Administrative Theory \& Praxis, 20(4):452-467. URL: http://www.jstor.org/stable/25611309.

Aizenman J., (2005). Financial Liberalizations in Latin America in the 1990s: A reassessment. NBER working paper series, 11145:1-30. URL: https://www.nber.org/papers/w11145.

Akella A.K., Saini R.P., Sharma M.P., (2009). Social, economical and environmental impacts of renewable energy systems. Renewable Energy, 34(2):390-396. doi: 10.1016/j.renene.2008.05.002. 
Apergis N., Payne J.E., (2014). Renewable energy, output, CO2 emissions, and fossil fuel prices in Central America: Evidence from a nonlinear panel smooth transition vector error correction model. Energy Economics, 42:226-232. doi: 10.1016/j.eneco.2014.01.003.

Asumadu-Sarkodie S., Owusu P.A., (2016). The relationship between carbon dioxide and agriculture in Ghana: a comparison of VECM and ARDL model. Environmental Science and Pollution Research, 23(11):10968-10982. Doi 10.1007/s11356-016-6252$\mathrm{x}$.

Aydoğan B., Vardar G., (2019). Evaluating the role of renewable energy, economic growth and agriculture on $\mathrm{CO} 2$ emission in E7 countries. International Journal of Sustainable Energy, p.1-15.doi: https://doi.org/10.1080/14786451.2019.1686380.

Aye G.C., Edoja P.E., (2017). Effect of economic growth on CO2 emission in developing countries: Evidence from a dynamic panel threshold model. Journal Cogent Economics \& Finance, 5(1):1-22. doi: 10.1080/23322039.2017.1379239.

Baharumshah A.Z., Mohd S.H., Mashi A.M.M., (2009). The stability of money demand in China: Evidence from the ARDL model. Economic Systems, 33(3):231-244. doi: 10.1016/j.ecosys.2009.06.001.

Balza L.H., Espinasa R., Serebrisky T., (2016). Lights on? Energy Needs in Latin America and the Caribbean to 2040. Inter-American Development Bank, p.1-39. URL: https://publications.iadb.org/en/publication/17053/lights-energy-needs-latin-americaand-caribbean-2040.

Bárcena A., Samaniego J., Galindo L.M., Carbonell J.F., Alatorre J.E., Stockins P., Reyes O., Sánchez L., Mostacedo J., (2019). A economia da mudança climática na América Latina e no Caribe. CEPAL, p. 1-61. URL: https://repositorio.cepal.org/bitstream/handle/11362/44486/1/S1801217_pt.pdf.

Bilgili F., Koçak E., Bulut Ü., (2016). The dynamic impact of renewable energy consumption on CO2 emissions: A revisited Environmental Kuznets Curve approach. Renewable and Sustainable Energy Reviews, 54:838-845. doi: 10.1016/j.rser.2015.10.080.

Breusch T.S, Pagan A.R., (1980). The Lagrange multiplier test and its applications to model specification in econometrics. The Review of Economic Studies, 47(1): 239-253. URL: https://www.jstor.org/stable/2297111.

Carneiro R.M., (2012). Commodities, choques externos e crescimento: reflexões sobre a América Latina. CEPAL, 117:1-47. ISSN:1680-8843. URL: http://www.eco.unicamp.br/cecon/images/arquivos/observatorio/Commodities_choque s_externos_crescimento.pdf.

Economic Commission for Latin America and the Caribbean (ECLAC), (2018). Foreign Direct Investment in Latin America and the Caribbean moves away from natural resources. ECLAC, p.1-4. ISSN:2522-7424. URL: https://repositorio.cepal.org/bitstream/handle/11362/43423/1/S1800258_en.pdf.

Engle R.F, Granger C.W.J., (1987). Cointegration and Error Correction: Representation, Estimation and Testing. Econometrica, 55:251-276. URL: https://www.jstor.org/stable/1913236.

Ertugrul H.M., Cetin M., Seker F., Dogan E., (2016). The impact of trade openness on global carbon dioxide emissions: Evidence from the top ten emitters among developing countries. Ecological Indicators, 67:543-555. doi: 10.1016/j.ecolind.2016.03.027.

Farhani S., Ozturk I., (2015). Causal relationship between CO2 emissions, real GDP, energy consumption, financial development, trade openness, and urbanization in Tunisia. Environmental Science and Pollution Research, 22(20):15663-15676. doi: 10.1007/s11356-015-4767-1. 
Flavin C., Gonzalez M., Majano A.M., Ochs A., Rocha M., Tagwerker P., (2014) Study on the Development of the Renewable Energy Market in Latin America and the Caribbean. IDB, 2(14):1-79.

URL: https://publications.iadb.org/publications/english/document/Study-on-the-

Development-of-the-Renewable-Energy-Market-in-Latin-America-and-theCaribbean.pdf.

Fuinhas J.A., Marques A.C., Koengkan M., (2014). Are renewable energy policies upsetting carbon dioxide emissions? The case of Latin America countries. Environmental Science and Pollution Research, 24(17): 15044-15054. doi: 10.1007/s11356-017-9109$\mathrm{z}$.

Fuinhas J.A., Marques A.C., Koengkan M., Santiago R., Couto A.P., (2019). The energy-growth nexus within production and oil rents context. Revista de Estudos Sociais, 21(42):161173. doi: $10.19093 /$ res7857.

Ghani G.M., (2012). Does trade liberalization effect energy consumption? Energy Policy, 43:285290. doi: 10.1016/j.enpol.2012.01.005.

Gielen D., Boshell F., Saygin D., Bazilian M.D., Wagner N., Gorini R., (2019). The role of renewable energy in the global energy transformation. Energy Strategy Reviews, 24:3850. doi: 10.1016/j.esr.2019.01.006.

Granger C.W.J., (1981). Some Properties of Time Series Data and Their Use in Econometric Model Specification. Journal of Econometrics, 28: 121-130. doi: 10.1016/03044076(81)90079-8.

Greene W., (2002). Econometric Analysis. Saddle River, New Jersey: Prentice-Hall.

Hauff J., Bode A., Neumann D., Haslauer F., (2014). Global Energy Transitions a comparative analysis of key countries and implications for the international energy debate. World energy council, p.1-30. URL: https://www.extractiveshub.org/resource/view/id/13542.

Hofman A.A., (2000). The economic development of Latin America in the twentieth century. Edward Elgar Publishing, Inc. Northampton, Massachusetts 01060 USA, p.1-338. ISBN:1 $85898 \quad 852 \quad 7 . \quad$ URL: https://repositorio.cepal.org/bitstream/handle/11362/1650/1/S33098H713E_en.pdf.

Hollanda L., Nogueira R., Muñoz R., Febraro J., Varejão M., Silva T.B., (2016). Eine vergleichende Studie über die Energiewende in Lateinamerika und Europa. EKLA-KAS and FGV Energia, p.1-72. URL: https:/www.kas.de/web/energie-klimalateinamerika/publikationen/einzeltitel/-/content/eine-vergleichende-studie-ueber-dieenergiewende-in-lateinamerika-und-europa1.

Holtz-Eakin D., Newey W., Rosen H.S., (1988). Estimating vector autoregressions with panel data. Econometrica, 56(6):1371-1395. doi: https://www.jstor.org/stable/1913103.

Intergovernmental Panel on Climate Change (IPCC), (2014). Climate Change 2014: Synthesis Report. Intergovernmental Panel on Climate Change, p. 1-169. ISBN 978-92-9169-1432.URL:

https://www.ipcc.ch/site/assets/uploads/2018/05/SYR_AR5_FINAL_full_wcover.pdf.

International Renewable Energy Agency (IRENA), (2016). Renewable energy market analysis: Latin America. IRENA, p. 1-16. ISBN:978-92-95111-50-9.URL: https://www.irena.org//media/Files/IRENA/Agency/Publication/2016/IRENA_Market _Analysis_Latin_America_summary_EN_2016.pdf?la=en\&hash=979D55D82A25782 6C0AAE4105C7F2BE37C60DF80.

Jácome L. H., (2004). The Late 1990s Financial Crisis in Ecuador: Institutional Weaknesses, Fiscal Rigidities, and Financial Dollarization at Work. IMF Working Paper: Monetary and Financial Systems Department, WP/04/12, p.1-47. URL: https://www.imf.org/external/pubs/ft/wp/2004/wp0412.pdf. 
Johansen S., Juselius K., (1990). Maximum Likelihood Estimation and Inference on Cointegration with Applications to the Demand for Money. Oxford Bulletin of Economics and Statistics,52(2): 169-210. doi: 10.1111/j.14680084.1990.mp52002003.x.

Khan M.A., Khan M.Z., Zaman K., Naz L., (2014). Global estimates of energy consumption and greenhouse gas emissions. Renewable and Sustainable Energy Reviews, 29:336-344. doi: 10.1016/j.rser.2013.08.091.

Kirkpatrick C., Scrieciu S.S., (2008) Is trade liberalization bad for the environment? A review of the economic evidence. Journal of Environmental Planning and Management, 51(4): 497-510. doi: 10.1080/09640560802116988.

Koengkan M., (2018b). The positive influence of urbanization on energy consumption in Latin American countries: an approach with ARDL and NARDL modelling. Revista de Estudos Sociais, 20(40):1-21. doi:10.19093/res5277.

Koengkan M., (2018c). The decline of environmental degradation by renewable energy consumption in the MERCOSUR countries: an approach with ARDL modelling. Environment Systems and Decisions, 38(3): 415-425. doi: 10.1007/s10669-018-9671$\mathrm{z}$.

Koengkan M., Fuinhas J.A., (2017). The Negative Impact of Renewable Energy Consumption on Carbon Dioxide Emissions: An empirical evidence from South American Countries. Revista Brasileira de Energias Renováveis, 6(5):893-914. doi: 10.5380/rber.v6i5.49252.

Koengkan M., Fuinhas J.A., Marques A.C., (2018b). Does financial openness increase environmental degradation? Fresh evidence from MERCOSUR countries. Environmental Science and Pollution Research, 25(30): 30508-30516. doi: 10.1007/s11356-018-3057-0.

Koengkan M., Fuinhas J.A., Marques A.C., (2019b). The role of financial openness and China's income on fossil fuels consumption: fresh evidence from Latin American countries. GeoJournal, p.1-15. doi: 10.1007/s10708-019-09969-1.

Koengkan M., Fuinhas J.A., Marques A.C., (2019f). The relationship between financial openness, renewable and nonrenewable energy consumption, $\mathrm{CO} 2$ emissions, and economic growth in the Latin American countries: an approach with a panel vector auto regression model. The Extended Energy-Growth Nexus: Theory and Empirical Applications, p.199-229. doi: 10.1016/B978-0-12-815719-0.00007-3.

Koengkan M., Fuinhas J.A., Vieira I., (2019d). Effects of financial openness on renewable energy investments expansion in Latin American countries. Journal of Sustainable Finance \& Investment, p. 1-19. doi: 10.1080/20430795.2019.1665379.

Koengkan M., Losekann L.D., Fuinhas J.A., Marques A.C., (2018a). The effect of hydroelectricity consumption on environmental Degradation-The case of South America region. TAS Journal, 2(2):46-67. ISSN:2595-1521.

Koengkan M., Poveda Y.E., Fuinhas J.A., (2019c). Globalisation as a motor of renewable energy development in Latin America countries. GeoJournal, p.1-12. doi: 10.1007/s10708-01910042-0.

Koengkan M., Santiago R., Fuinhas J.A., (2019e). The impact of public capital stock on energy consumption: Empirical evidence from Latin America and the Caribbean region. International Economics, p.1-20. doi: 10.1016/j.inteco.2019.09.001.

Koengkan M., Santiago R., Fuinhas J.A., Marques A.C., (2019a). Does financial openness cause the intensification of environmental degradation? New evidence from Latin American and Caribbean countries. Environmental Economics and Policy Studies, p.1-26. doi: 10.1007/s10018-019-00240-y. 
Kuik O., Gerlagh R., (2003). Trade Liberalization and Carbon Leakage. The Energy Journal, 24(3):97-120. URL: https://www.jstor.org/stable/41323001.

Kukla-Gryz A., (2009). Economic growth, international trade and air pollution: A decomposition analysis. Ecological Economics, 68(1):1329-1339. doi: 10.1016/j.ecolecon.2008.09.005.

Lee C.G., (2010). Health care and tourism: Evidence from Singapore. Tourism Management,31(4):486-488. doi: 10.1016/j.tourman.2009.05.002.

Leitão N.C., (2014). Economic Growth, Carbon Dioxide Emissions, Renewable Energy and Globalization.International Journal of Energy Economics and Policy, 4(3):391-399. ISSN: 2146-4553. URL: https://core.ac.uk/download/pdf/70620032.pdf.

Mardani A., Streimikiene D., Cavallaro F., Loganathan N., Khoshnoudi M., (2019). Carbon dioxide (CO2) emissions and economic growth: A systematic review of two decades of research from 1995 to 2017. Science of The Total Environment, 649:31-49. doi: 10.1016/j.scitotenv.2018.08.229.

Martins, M.L.R., (2002). Meio ambiente e morada social nos países do Mercosul. Madrid, p. 303313.

Mbarek M.B., Saidi K., Amamri M., (2018). The relationship between pollutant emissions, renewable energy, nuclear energy and GDP: empirical evidence from 18 developed and developing countries. International Journal of Sustainable Energy, 37(6):597-615. doi: https://doi.org/10.1080/14786451.2017.1332060.

Mirza F.M., Kanwal A., (2017). Energy consumption, carbon emissions and economic growth in Pakistan: Dynamic causality analysis. Renewable and Sustainable Energy Reviews,72:1233-1240. doi: 10.1016/j.rser.2016.10.081.

Narayan P.K., (2015). Fiji's Tourism Demand: The ARDL Approach to Cointegration. Tourism Economics, 10(2):193-206. doi: 10.5367/000000004323142425.

Nkoro E., Uko A.K. (2016). Autoregressive Distributed Lag (ARDL) cointegration technique: application and interpretation. Journal of Statistical and Econometric Methods, 5(4): 6391. ISSN: 1792-6602. URL: http://www.scienpress.com/Upload/JSEM\%2fVol\%205_4_3.pdf.

OECD Environment Directorate (2008). OECD key environmental indicators. OECD, p.1-38. URL: https://www.oecd.org/env/indicators-modelling-outlooks/37551205.pdf.

Omri A., Nguyen D. K., Rault C., (2014). Causal interactions between CO2 emissions, FDI, and economic growth: Evidence from dynamic simultaneous-equation models. Economic Modelling, 42:382-389. doi: 10.1016/j.econmod.2014.07.026.

Pesaran M. H., (2007). A simple panel unit root test in the presence of cross-section dependence. Journal of Applied Econometrics, 22(2):265-312. doi: 10.1002/jae.951.

Pesaran M.H., (2004). General diagnostic tests for cross section dependence in panels. The University of Cambridge, Faculty of Economics. Cambridge Working Papers in Economics, 435. URL: http://ftp.iza.org/dp1240.pdf.

Pesaran M.H., Shin Y., Smith R.P., (1999). Pooled mean group estimation of dynamic heterogeneous panels. Journal of American Statistical Association, 94(446): 621-634. URL: http://www.jstor.org/stable/2670182.

Pesaran M.H., Smith R., (1995). Estimating long-run relationships from dynamic heterogeneous panels. Journal of Econometrics, 68(1):79-113. doi: 10.1016/0304-4076(94)01644-F.

Sadorsky P., (2009). Renewable energy consumption, CO2 emissions and oil prices in the G7 countries. Energy Economics, 31(3):456-462. doi: 10.1016/j.eneco.2008.12.010. 
Santiago R., Koengkan M., Fuinhas J.A., Marques A.C., (2019). The relationship between public capital stock, private capital stock and economic growth in the Latin American and Caribbean countries. International Review of Economics, p. 1-25.doi: 10.1007/s12232019-00340-x.

Santos B.G., (2015). O ciclo econômico da América Latina dos últimos 12 anos em uma perspectiva de restrição externa. Revista do BNDES 43:205-251. URL: https://web.bndes.gov.br/bib/jspui/bitstream/1408/6242/2/RB\%2043\%20O\%20ciclo\% 20 econ $\%$ C3\%B4mico\%20da\%20Am\%C3\%A9rica\%20Latina_P\%20.pdf.

Sebri M., Ben-Salha O., (2014). On the causal dynamics between economic growth, renewable energy consumption, $\mathrm{CO} 2$ emissions and trade openness: fresh evidence from BRICS countries. Renewable and Sustainable Energy Reviews, 39:14-23. doi: 10.1016/j.rser.2014.07.033.

Shafiei S., Salim R.A., (2014). Non-renewable and renewable energy consumption and CO2 emissions in OECD countries: A comparative analysis. Energy Policy, 66:547-556. doi: 10.1016/j.enpol.2013.10.064.

Shahbaz M., Bhattacharya M., Ahmed K., (2015a). Growth-Globalisation-Emissions Nexus: The Role of Population in Australia. Department of economics, 23(15):1-32. ISSN: 14415429 .

Shahbaz M., Loganathan N., Sbia R., Afza T., (2015b). The effect of urbanization, affluence and trade openness on energy consumption: A time series analysis in Malaysia. Renewable and Sustainable Energy Reviews, 57:683-693. doi: 10.1016/j.rser.2015.03.044.

Shahbaz M., Mallick H., Mahalik M.H., Sadorsky P., (2016). The role of globalization on the recent evolution of energy demand in India: Implications for sustainable development. Energy Economics, 55:52-68. doi: 10.1016/j.eneco.2016.01.013.

Shahbaz M., Nasreen S., Ling C.H., Sbia R., (2014). Causality between trade openness and energy consumption: What causes what in high, middle and low-income countries. Energy Policy, 70:126-143. doi: 10.1016/j.enpol.2014.03.029.

Smil V., (2010). Energy Transitions: History, Requirements, Prospects. Praeger Publishers, Santa Barbara, CA. ISBN-10: 0313381771.

Solomon B.D., Krishna K., (2011). The coming sustainable energy transition: History, strategies, and outlook. Energy Policy, 39(11):7422-7431. doi: 10.1016/j.enpol.2011.09.009.

Terra M.I., (2003). Trade liberalization in Latin American countries and the agreement on textiles and clothing in the WTO. Économie internationale, 94(95):137-154. ISSN 1240-8093. URL: https://www.cairn.inforevue-economie-internationale-2003-2-page-137.htm.

The Carter Center. President Carter Leads Delegation to Negotiate Peace With Haiti, 1994. URL: https://www.cartercenter.org/news/documents/doc218.html.

United Nations Environment Programme (UNEP), (2001). Climate change: Information kit. United Nations Environment Programme, p. 1-63. URL: https://unfccc.int/resource/iuckit/cckit2001en.pdf.

Vásquez I., (1996). The Brady plan and market-based solutions to debt crises. Cato Journal, 16(2):1-11. URL: https://www.cato.org/sites/cato.org/files/serials/files/catojournal/1996/11/cj16n2-4.pdf.

Ventura-Dias V., Cabezas M., Contador J., (1999). Trade reforms and trade patterns in Latin America. CEPAL, 5:1-53. ISBN:92-1-121256-1. URL: https://pdfs.semanticscholar.org/56a4/464b039b3e19246894fa2de5fdc8bbf308ef.pdf.

Wooldridge J.M., (2002). Econometric analysis of cross section and panel data. The MIT Press Cambridge, Massachusetts London, England. URL: 
https://jrvargas.files.wordpress.com/2011/01/wooldridge _j-

_2002_econometric_analysis_of_cross_section_and_panel_data.pdf.

World Bank Open Data., (2019). URL: http://www.worldbank.org/.

World Energy Council, (2019). World Energy Issues Monitor 2019. World Energy Council, p.1207, 2019. URL: https://www.worldenergy.org/wp-content/uploads/2019/02/1.-WorldEnergy-Issues-Monitor-2019-Interactive-Full-Report.pdf.

Zahonogo P., (2016). Trade and economic growth in developing countries: Evidence from subSaharan Africa. Journal of African Trade, 3(1-2):41-56. doi: 10.1016/j.joat.2017.02.001.

Appendix

Carbon dioxide emissions $(\mathrm{CO} 2)$ in Kilotons $(\mathrm{Kt})$ per capita in Latin America \& Caribbean (1970-2014)

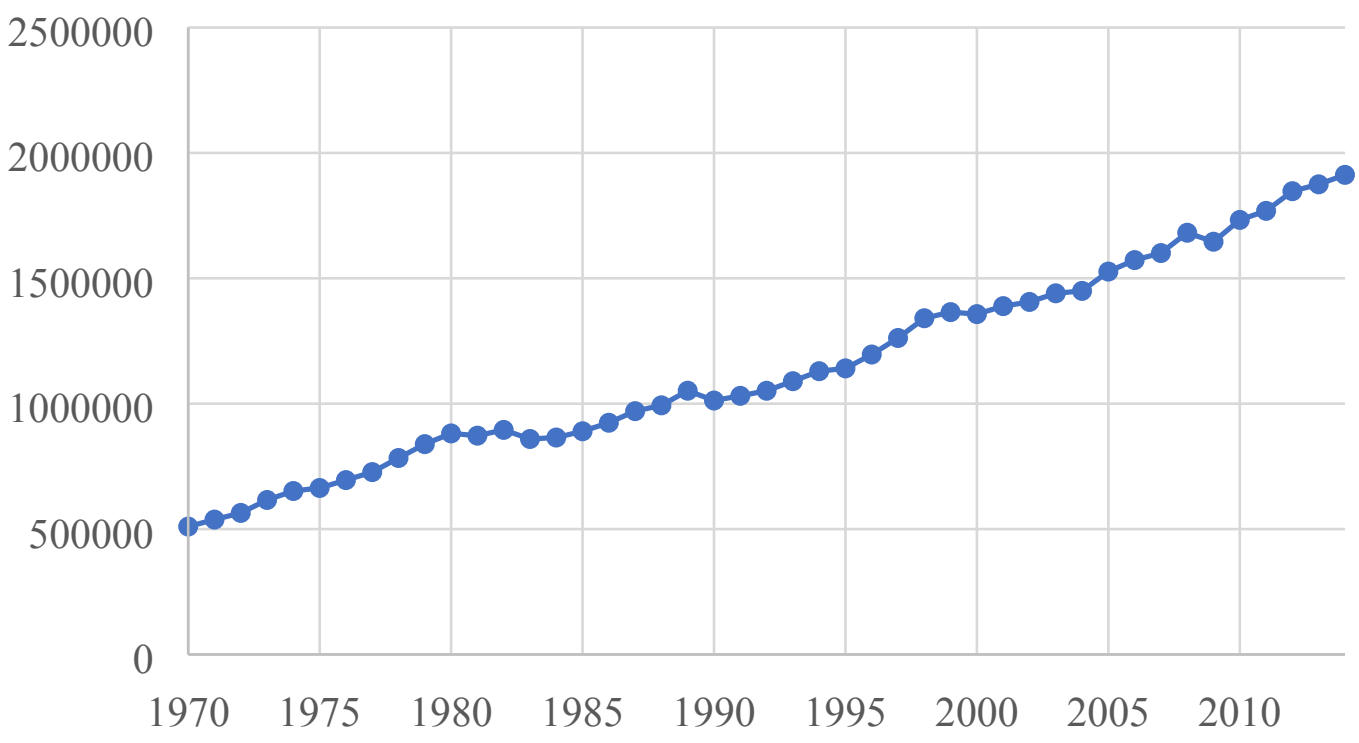

Figure 1. Evolution of Carbon dioxide emissions $(\mathrm{CO} 2)$ in Kilotons $(\mathrm{Kt})$ per capita in Latin America \& Caribbean (1989-2014). This graph was created with the database from the World Bank Open Data, (2019). URL: http://www.worldbank.org/. 


\section{GDP per capita (current US\$) in Latin America \& Caribbean} (1989-2014)

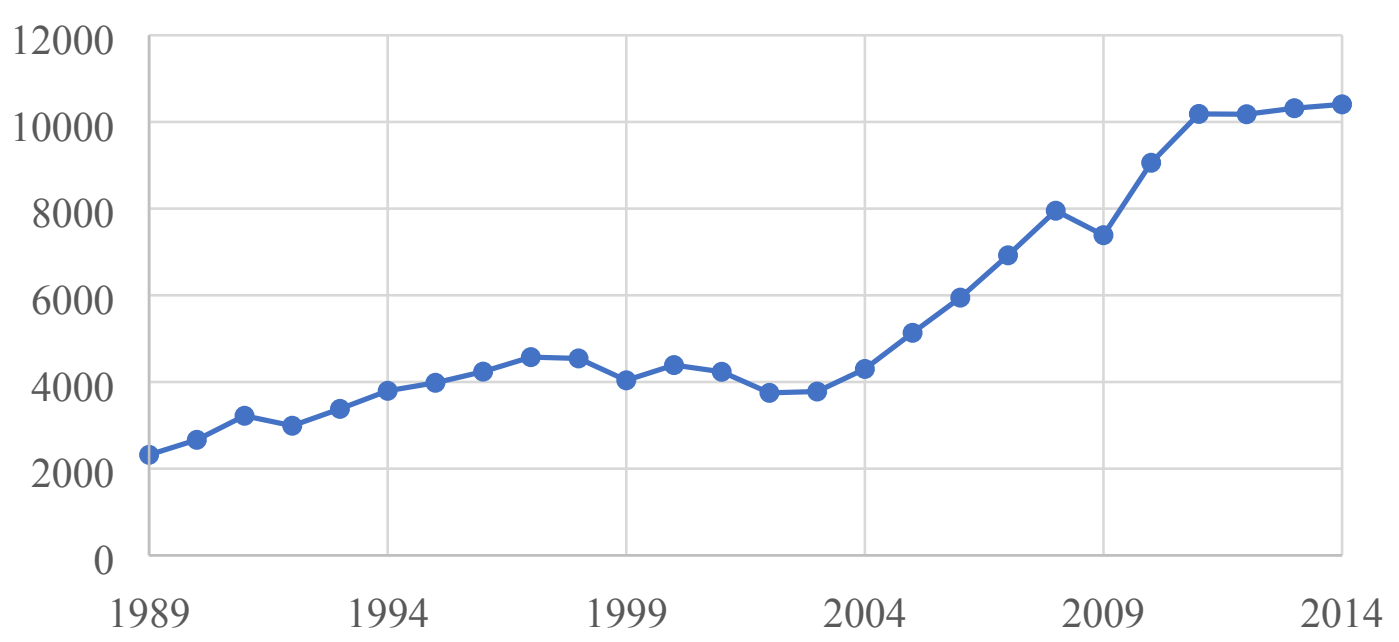

Figure 2. Evolution of GDP per capita (current US\$) in Latin America \& Caribbean (1989-2014). This graph was created with the database from the World Bank Open Data, (2019). URL: http://www.worldbank.org/.

Electric power consumption (kWh per capita) in Latin America \& Caribbean (1989-2014)

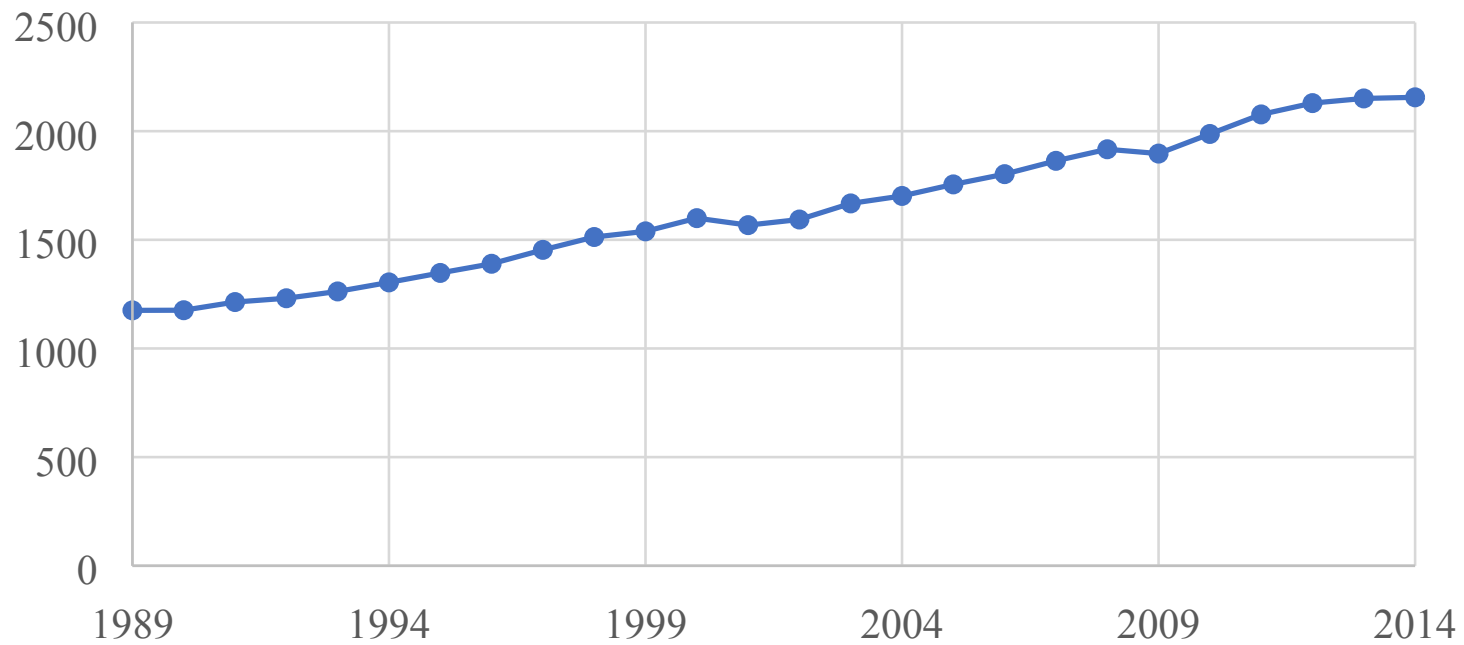

Figure 3. Evolution of Electric power consumption (kWh per capita) in Latin America \& Caribbean (1989-2014). This graph was created with the database from the World Bank Open Data, (2019).URL: http://www.worldbank.org/. 


\section{Renewable and fossil fuels energy consumption (\% of Total energy consumption) in Latin America \& Caribbean (1989-2014)}

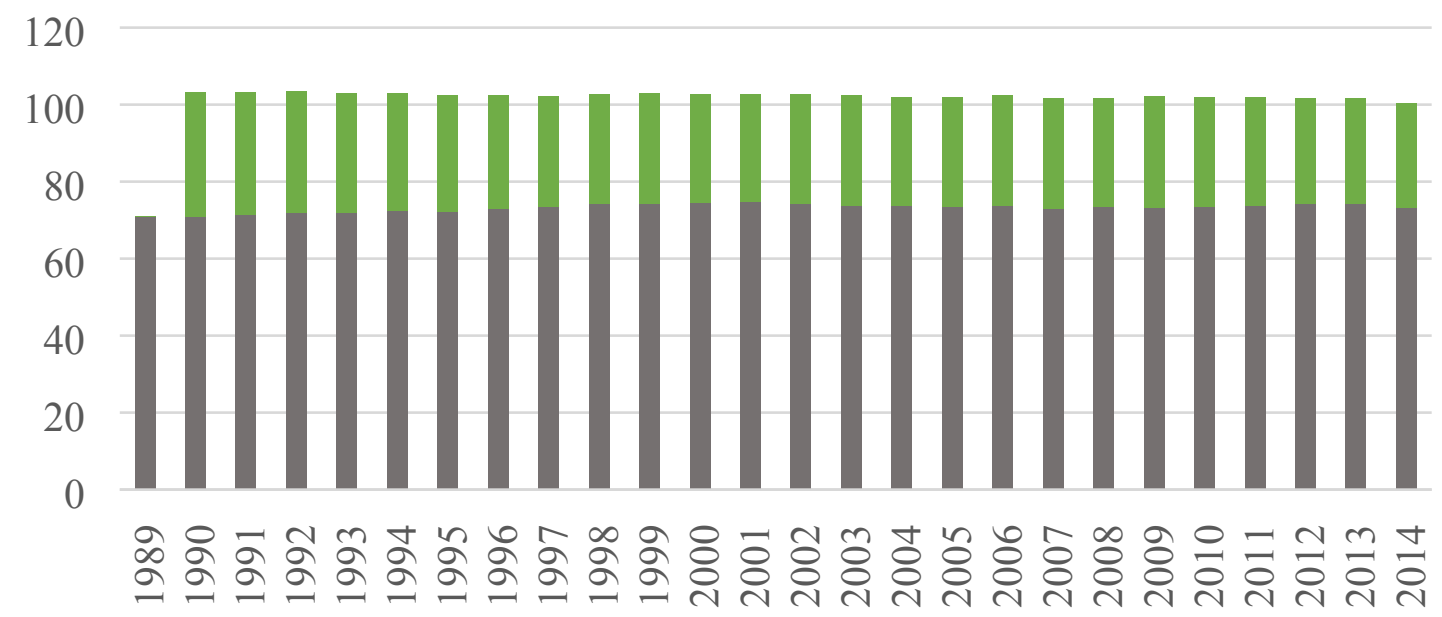

- Fossil fuel energy consumption Renewable energy consumption

Figure 4. Evolution of Renewable and fossil fuels energy consumption (\% of total energy consumption) in Latin America \& Caribbean (1989-2014). This graph was created with the database from the World Bank Open Data, (2019). URL: http://www.worldbank.org/.

Trade (\% of GDP) in Latin America \& Caribbean (19892014)

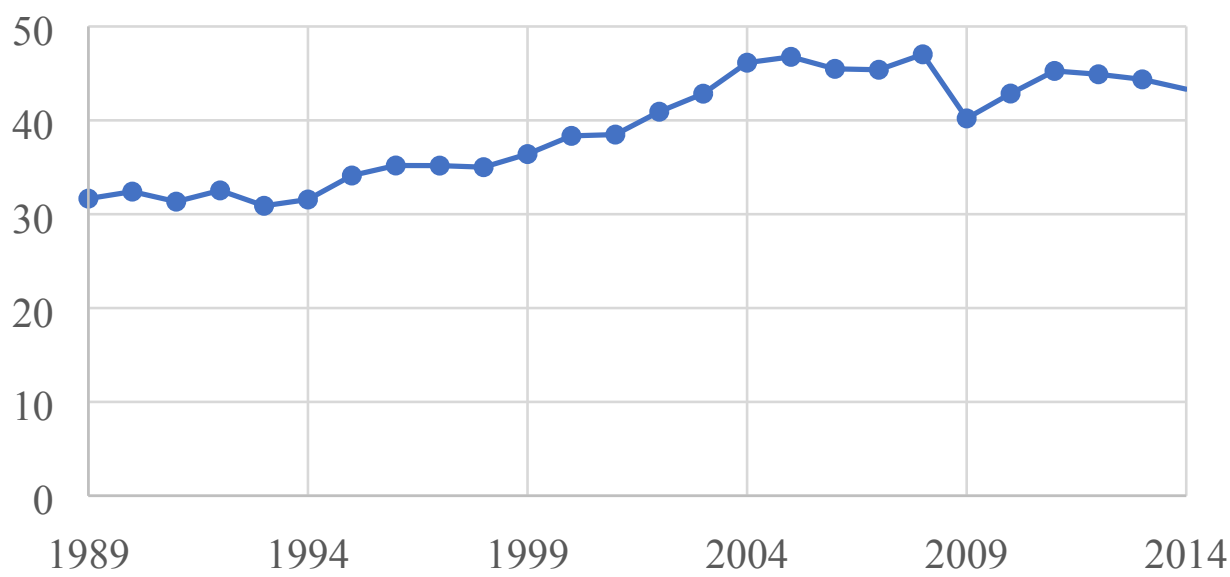

Figure 5 Evolution of Trade (\% of GDP) in Latin America \& Caribbean (1989-2014). This graph was created with the database from the World Bank Open Data, (2019). URL: http://www.worldbank.org/. 
Exports and Imports of goods and services per capita (BoP, current US\$) in Latin America \& Caribbean (1989-2014)

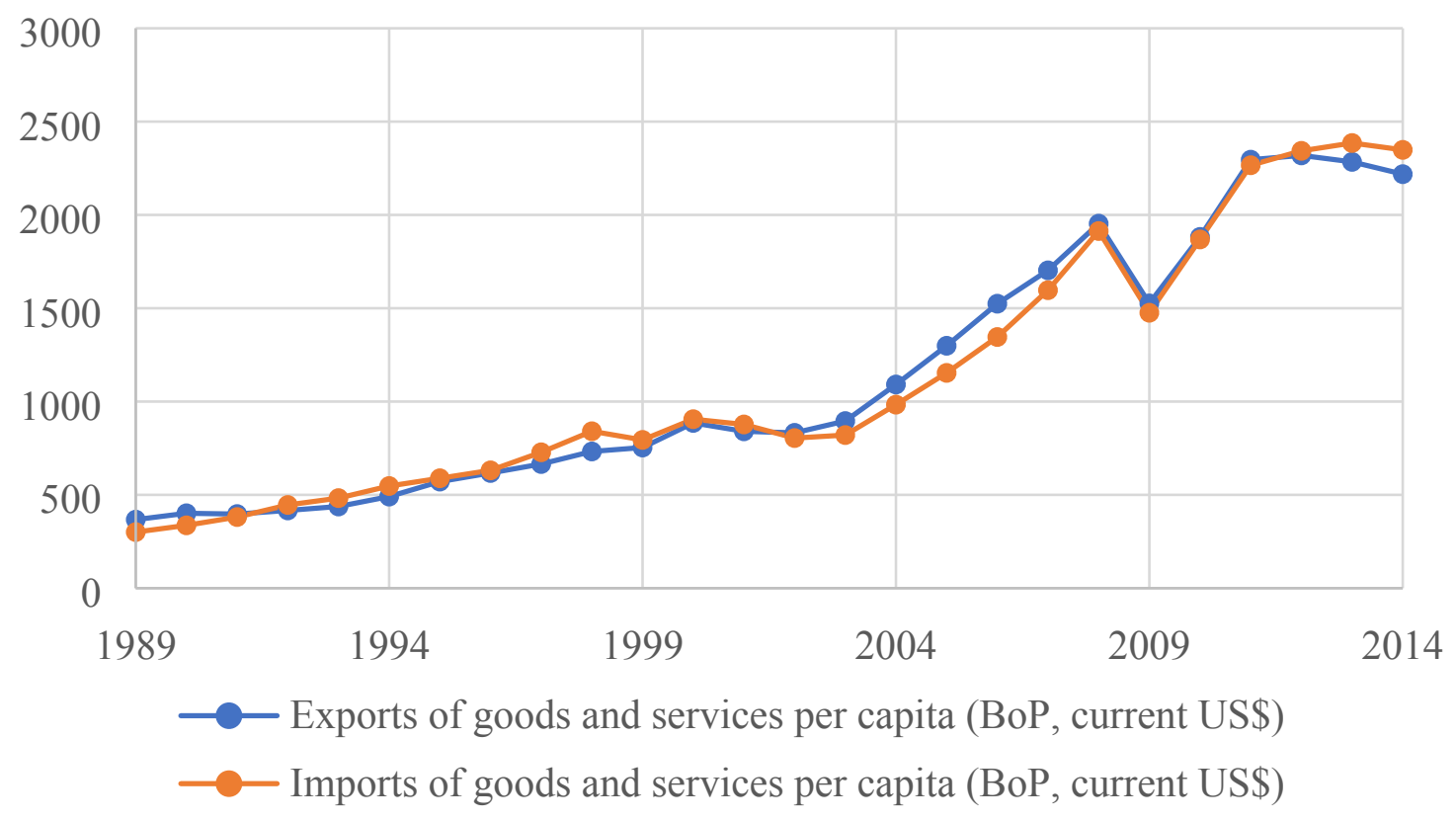

Figure 6. Evolution of Exports and Imports of goods and services per capita (BoP, current US\$) in Latin America \& Caribbean between (1989-2014). This graph was created with the database from the World Bank Open Data, (2019).URL: http://www.worldbank.org/. 